BACteRIOLOGICAL QuALITY OF

Ground WATER USED FOR HOUSEHOLd SUPPLY,

LOWER SusQueHANNA RIVER BASIN,

Pennsylvania and Maryland

U.S. Department of the Interior

u.S. Geological Survey

Water-Resources Investigations Report 96-4212

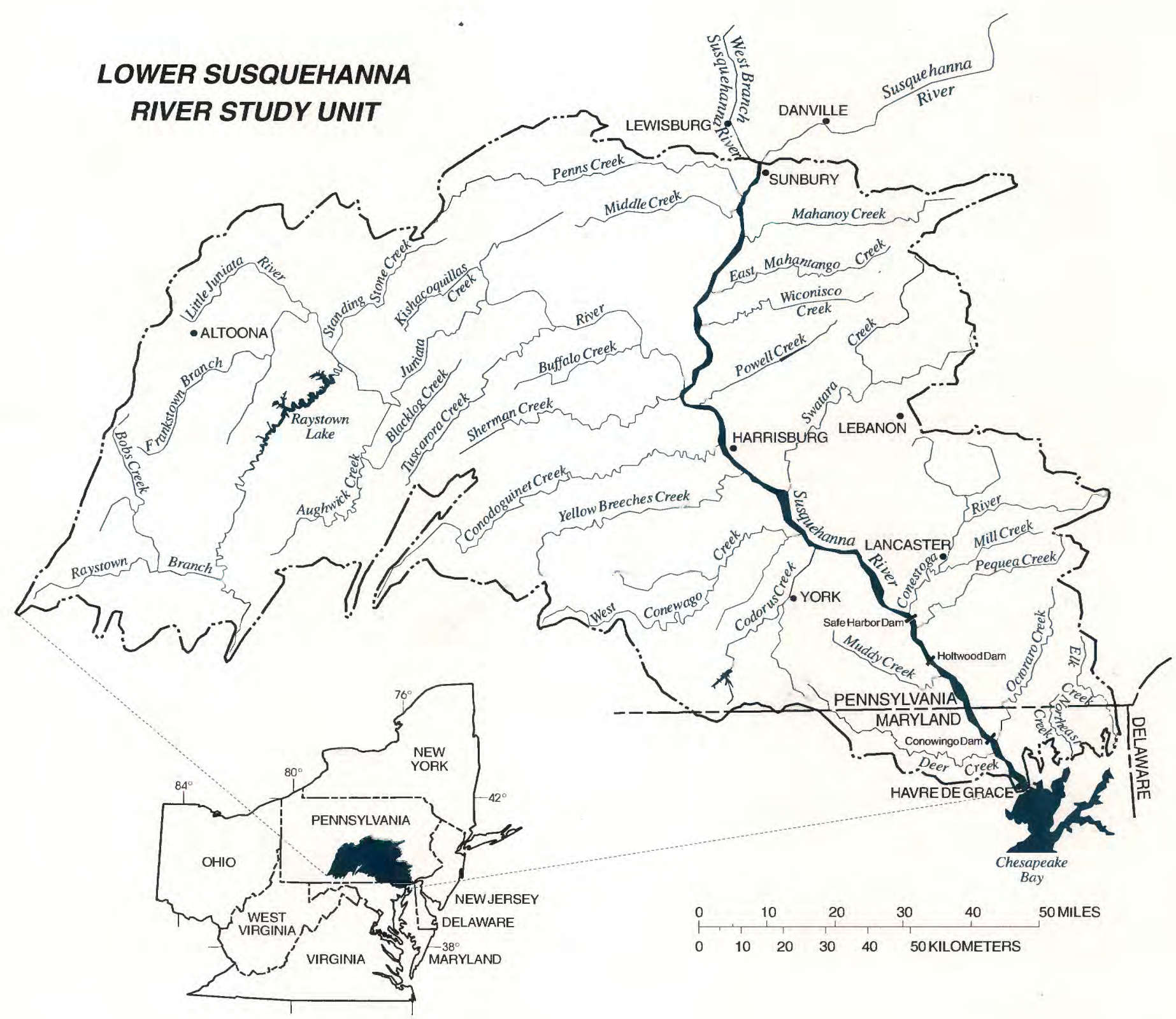

NATIONAL WATER-QUALITY ASSESSMENT PROGRAM

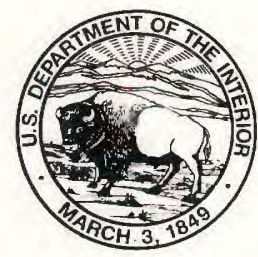


BACTERIOLOGICAL QUALITY OF

Ground WATER USEd for Household SupPLy,

LOWER SusqueHanNa River Basin,

Pennsylvania and Maryland

Tammy M. Bickford, Bruce D. Lindsey, and Mark R. Beaver

U.S. Department of the Interior

U.S. Geological Survey

Water-Resources Investigations Report 96-4212

NATIONAL WATER-QUALITY ASSESSMENT PROGRAM

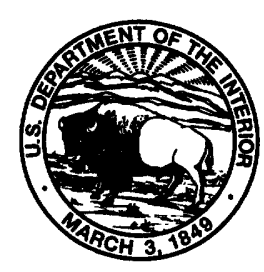

Lemoyne, Pennsylvania

1996 


\section{U.S. DEPARTMENT OF THE INTERIOR \\ BRUCE BABBITT, Secretary}

\section{U.S. GEOLOGICAL SURVEY \\ Gordon P. Eaton, Director}

Use of any trade, product, or firm names in this publication is for descriptive purposes only and does not imply endorsement by the U.S. Government.

For additional information write to:

\section{District Chief}

U.S. Geological Survey

840 Market Street

Lemoyne, Pennsylvania 17043-1586
Copies of this report may be purchased from:

U.S. Geological Survey

Branch of Information Services

Box 25286

Denver, Colorado 80225-0286

Information regarding the National Water-Quality Assessment (NAWQA) Program is available on the Internet via the World Wide Web. You may connect to the NAWQA Home Page using the Universal Resource Locator (URL) at:

<URL:http://wwwrvares.er.usgs.gov/nawqa/nawqa_home.html> 


\section{FOREWORD}

The mission of the U.S. Geological Survey (USGS) is to assess the quantity and quality of the earth resources of the Nation and to provide information that will assist resource managers and policymakers at Federal, State, and local levels in making sound decisions. Assessment of water-quality conditions and trends is an important part of this overall mission.

One of the greatest challenges faced by water-resources scientists is acquiring reliable information that will guide the use and protection of the Nation's water resources. That challenge is being addressed by Federal, State, interstate, and local water-resource agencies and by many academic institutions. These organizations are collecting water-quality data for a host of purposes that include: compliance with permits and water-supply standards; development of remediation plans for specific contamination problems; operational decisions on industrial, wastewater, or water-supply facilities; and research on factors that affect water quality. An additional need for water-quality information is to provide a basis on which regional- and national-level policy decisions can be based. Wise decisions must be based on sound information. As a society we need to know whether certain types of water-quality problems are isolated or ubiquitous, whether there are significant differences in conditions among regions, whether the conditions are changing over time, and why these conditions change from place to place and over time. The information can be used to help determine the efficacy of existing water-quality policies and to help analysts determine the need for and likely consequences of new policies.

To address these needs, the U.S. Congress appropriated funds in 1986 for the USGS to begin a pilot program in seven project areas to develop and refine the National Water-Quality Assessment (NAWQA) Program. In 1991, the USGS began full implementation of the program. The NAWQA Program builds upon an existing base of water-quality studies of the USGS, as well as those of other Federal, State, and local agencies. The objectives of the NAWQA Program are to:

- Describe current water-quality conditions for a large part of the Nation's freshwater streams, rivers, and aquifers.

- Describe how water quality is changing over time.

- Improve understanding of the primary natural and human factors that affect waterquality conditions.

This information will help support the development and evaluation of management, regulatory, and monitoring decisions by other Federal, State, and local agencies to protect, use, and enhance water resources.

The goals of the NAWQA Program are being achieved through ongoing and proposed investigations of 60 of the Nation's most important river basins and aquifer systems, which are referred to as study units. These study units are distributed throughout the Nation and cover a diversity of hydrogeologic settings. More than two-thirds of the Nation's freshwater use occurs within the 60 study units and more than two-thirds of the people served by public water-supply systems live within their boundaries.

National synthesis of data analysis, based on aggregation of comparable information obtained from the study units, is a major component of the program. This effort focuses on selected water-quality topics using nationally consistent information. Comparative studies will explain differences and similarities in observed water-quality conditions among study areas and will identify changes and trends and their causes. The first topics addressed by the national 
synthesis are pesticides, nutrients, volatile organic compounds, and aquatic biology. Discussions on these and other water-quality topics will be published in periodic summaries of the quality of the Nation's ground and surface water as the information becomes available.

This report is an element of the comprehensive body of information developed as part of the NAWQA Program. The program depends heavily on the advice, cooperation, and information from many Federal, State, interstate, Tribal, and local agencies and the public. The assistance and suggestions of all are greatly appreciated.

\section{Robest m. Itirsch}

Robert M. Hirsch Chief Hydrologist 


\section{CONTENTS}

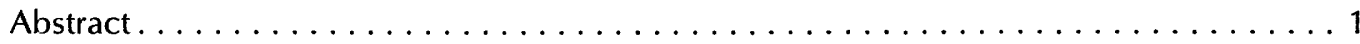

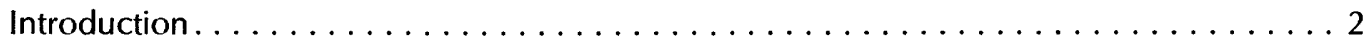

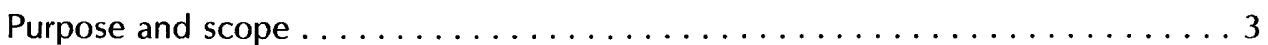

Bacteria and potability of ground water. . . . . . . . . . . . . 3

Regulations for private wells in Pennsylvania and Maryland. . . . . . . . . 4

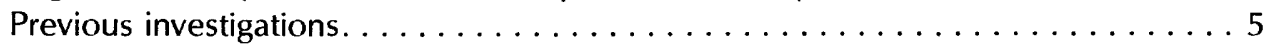

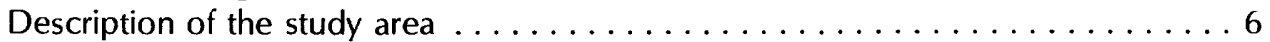

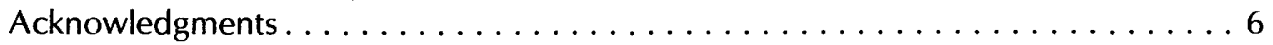

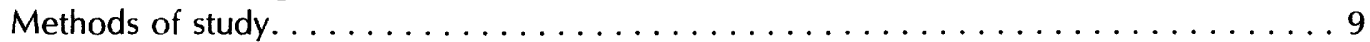

Microbiology................................ 10

Quality Assurance . . . . . . . . . . . . . . . . . . . . 11

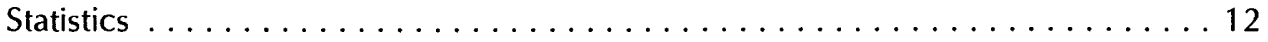

Bacteriological quality of ground water used for household supply $\ldots \ldots \ldots \ldots \ldots 13$

Relations between bacterial concentrations and land use, physiography,

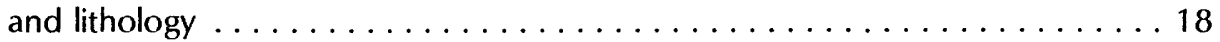

Relations between bacterial concentrations and selected well and water-quality characteristics ........................ 24

Other possible factors related to bacteria in ground water $\ldots \ldots \ldots \ldots \ldots 26$

Pathways for bacteria to enter into the well ............. 26

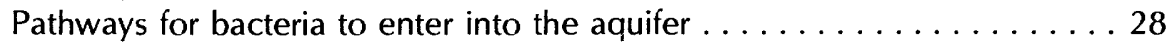

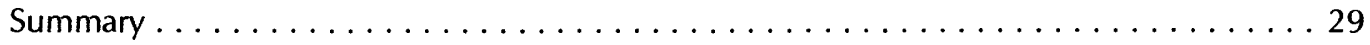

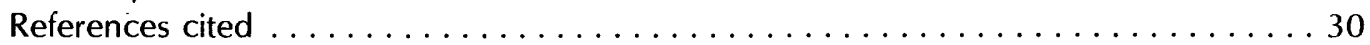




\section{ILLUSTRATIONS}

Figure 1. Map showing location of environmental subunits sampled and bedrock types, Lower Susquehanna River Basin study unit,

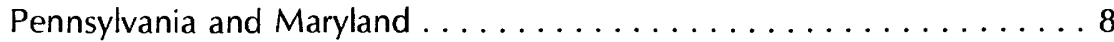

2. Barchart showing bacteria presence in ground water from wells sampled as part of the National Water-Quality Assessment in the Lower Susquehanna River Basin study unit, Pennsylvania and Maryland ............................. 13

3. Barchart showing the distribution of bacteria among count ranges in the ground water from wells sampled as part of the National WaterQuality Assessment in the Lower Susquehanna River Basin study unit, Pennsylvania and Maryland $\ldots \ldots \ldots \ldots \ldots \ldots \ldots \ldots \ldots$

4. Map showing sampling locations and detections for total coliform bacteria in ground water from wells sampled as part of the National Water-Quality Assessment in the Lower Susquehanna River Basin

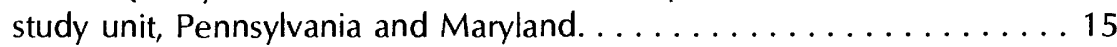

5. Map showing sampling locations and detections for fecal coliform bacteria in ground water from wells sampled as part of the National Water-Quality Assessment in the Lower Susquehanna River Basin study unit, Pennsylvania and Maryland. . . . . . . . . . . . 16

6. Bar charts showing the presence of total coliform, fecal coliform, E. coli and fecal streptococcus as a percentage of the number of wells sampled in each environmental subunit in the Lower Susquehanna River Basin study unit, Pennsylvania and Maryland. . . . 17

7. Boxplots showing the distribution of concentrations of total coliform and fecal streptococcus among land-use types, Lower Susquehanna River Basin study unit, Pennsylvania and Maryland ........... 19

8. Boxplots showing the distribution of concentrations of total coliform and fecal streptococcus among physiographic provinces, Lower Susquehanna River Basin study unit, Pennsylvania and Maryland. . . . . 20

9. Boxplots showing the distribution of concentrations of total coliform and fecal streptococcus among bedrock lithologies comprising aquifers, Lower Susquehanna River Basin study unit, Pennsylvania

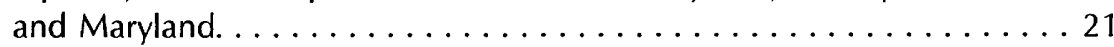

10. Boxplots showing the distribution of concentrations of total coliform and fecal streptococcus among land-use settings within environmental subunits, Lower Susquehanna River Basin study unit, Pennsylvania and Maryland. . . . . . . . . . . . . . . . . . . 22

11. Diagram showing pathways for bacterial contamination to enter

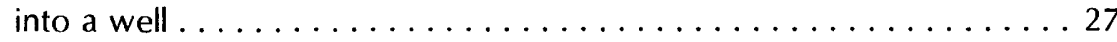

12. Diagram showing pathways for bacterial contamination to enter

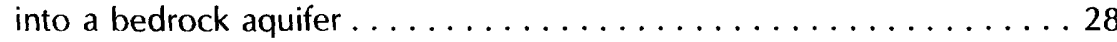




\section{TABLES}

Table 1. Private water-supply information from the 1990 U. S. Bureau of the Census for counties in the Lower Susquehanna River Basin study unit . . . 2

2. Environmental subunits and selected characteristics of wells representing subunits of the Lower Susquehanna River Basin study

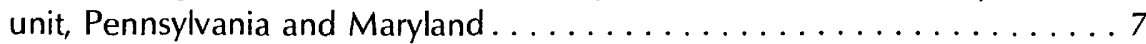

3. Summary of sample processing methods for determination of bacterial concentrations in well water . . . . . . . . . . . 10

4. Results of statistical analyses for relations between land use and bacterial concentrations, Lower Susquehanna River Basin study

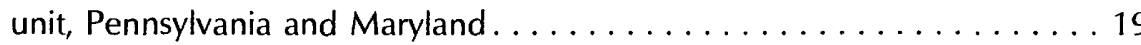

5. Results of statistical analyses for relations between physiography and bacterial concentrations, Lower Susquehanna River Basin study unit, Pennsylvania and Maryland...................... 20

6. Results of statistical analyses for relations between bedrock lithology comprising aquifer and bacterial concentrations, Lower Susquehanna River Basin study unit, Pennsylvania and Maryland . . . . . . . . 21

7. Results of statistical analyses for relations between land-use settings within environmental subunits and bacterial concentrations, Lower Susquehanna River Basin study unit, Pennsylvania and Maryland . . . . . . 23

8. Summary of statistical correlations between bacterial concentrations and selected well characteristics, Lower Susquehanna River Basin study unit, Pennsylvania and Maryland. . . . . . . . . . . 25

9. Summary of statistical correlations between bacterial concentrations and selected water-quality constituents, Lower Susquehanna River Basin study unit, Pennsylvania and Maryland. . . . . . . . . . 25 
ABBREVIATED WATER-QUALITY UNITS

Multiply

Length

foot ( $\mathrm{ft}$ )

square mile $\left(\mathrm{mi}^{2}\right)$

$\underline{\text { Volume }}$

gallon (gal)

Pressure

pound per square inch (psi)

Temperature

degree Fahrenheit $\left({ }^{\circ} \mathrm{F}\right)$

${ }^{\circ} \mathrm{C}=5 / 9\left({ }^{\circ} \mathrm{F}-32\right)$
6.895

To obtain

$\begin{array}{ll}0.3048 & \text { meter } \\ 2.590 & \text { square kilometer }\end{array}$

3.785

liter

kilopascal

degree Celsius

Other Abbreviations
$\mathrm{mL}$, milliliter
$\mu \mathrm{m}$, micrometer
L, liter
$\mathrm{mm}$, millimeter 


\title{
BACTERIOLOGICAL QUALITY OF \\ GROUND WATER USED FOR HOUSEHOLD SUPPLY, LOWER SUSQUEHANNA RIVER BASIN, PenNSYlVania AND Maryland
}

\author{
By Tammy M. Bickford, Bruce D. Lindsey, and Mark R. Beaver
}

\begin{abstract}
This report describes the bacteriological results of a ground-water study conducted from 1993 to 1995 as part of the U.S. Geological Survey's National Water-Quality Assessment Program in the Lower Susquehanna River Basin study unit. Water samples collected from 146 household supply wells were analyzed for fecal-indicator organisms including total coliform, fecal coliform, Escherichia coli (E. coli), and fecal streptococcus concentrations. Supporting data used in the interpretations are selected water-quality constituents, wellconstruction information, and the environmental setting at the well site including land use, physiography, and bedrock type. Water from nearly 70 percent of the wells sampled had total coliform present and thus was not suitable for drinking without treatment. Fecal coliforms were found in water from approximately 25 percent of the sampled wells. E. coli testing was not conducted in 1993. Approximately 30 percent of the 88 sampled wells had waters with $E$. coli. Fecal streptococcus bacteria was present in water from about 65 percent of the wells sampled. Bacteriological contamination was more likely to occur in water from wells in agricultural areas than in water from wells in forested areas. Water from wells sampled in the Ridge and Valley Physiographic Province was more likely to have bacteria than water from wells in the Piedmont Physiographic Province. Differences in bacterial concentrations among bedrock types are only statistically significant for $E$. coli. Bacterial concentrations are weakly related to well-age but not to other well characteristics such as the total well depth or the casing length. Relations exist between bacterial concentrations and selected water-quality constituents. Most wells from which water was sampled did not have sanitary seals and very few were grouted. This may have contributed to the number of detections of bacteria. It is uncertain whether the bacteria detected are the result of widespread aquifer contamination or sitespecific factors.
\end{abstract}




\section{INTRODUCTION}

The U.S. Geological Survey's (USGS) National Water-Quality Assessment (NAWQA) Program is designed to determine the occurrence and distribution of water-quality characteristics in ground water and surface water (Gilliom and others, 1995). Studies began in 1991 in the Lower Susquehanna River Basin study unit, hereafter termed the study unit. The occurrence and distribution of bacteria in ground water are important water-quality issues in the study unit.

Ground water is an important source of household supply in the study unit. Private water-supply information from the U.S. Bureau of the Census (1990) for counties in the study unit shows a total of nearly $1,600,000$ households, of which about 500,000 depend on ground water from private wells for their drinking water supply (table 1). Approximately 400,000 households are in Pennsylvania; the others are in Maryland. Because only parts of some counties are within the basin, these numbers overrepresent the number of households and private wells in the basin (table 1). To estimate the number of households and private wells, the number in each county was multiplied by the fraction of each county in the basin. Using this estimation, about 800,000 households and approximately 300,000 private wells are in the basin. Therefore, approximately 38 percent of the households in the study unit depend on ground water from private wells for water supply.

Table 1. Private water-supply information from the 1990 U.S. Bureau of the Census for counties in the Lower Susquehanna River Basin study unit

\begin{tabular}{|c|c|c|c|c|}
\hline County & $\begin{array}{l}\text { Number of } \\
\text { households }\end{array}$ & $\begin{array}{l}\text { Number of } \\
\text { households in } \\
\text { county with } \\
\text { private wells }\end{array}$ & $\begin{array}{l}\text { Percentage of } \\
\text { households in } \\
\text { county with } \\
\text { private wells }\end{array}$ & $\begin{array}{l}\text { Percentage of } \\
\text { county in the } \\
\text { Lower Susquehanna } \\
\text { River Basin }\end{array}$ \\
\hline Adams & 28,066 & 15,655 & 55 & 52 \\
\hline Baltimore (Md.) & 268,638 & 23,845 & 8 & 2 \\
\hline Bedford & 18,070 & 13,472 & 74 & 72 \\
\hline Berks & 127,849 & 38,847 & 30 & 11 \\
\hline Blair & 50,325 & 12,790 & 25 & 100 \\
\hline Carroll (Md.) & 42,213 & 24,704 & 58 & 1 \\
\hline Cecil (Md.) & 24,817 & 17,012 & 68 & 34 \\
\hline Centre & 42,784 & 6,986 & 16 & 27 \\
\hline Chester & 133,592 & 49,316 & 36 & 19 \\
\hline Columbia & 23,436 & 11,292 & 48 & 2 \\
\hline Cumberland & 73,506 & 19,587 & 26 & 100 \\
\hline Dauphin & 95,123 & 21,655 & 22 & 100 \\
\hline Franklin & 45,642 & 14,455 & 31 & 22 \\
\hline Fulton & 5,127 & 4,444 & 86 & 34 \\
\hline Harford (Md.) & 63,094 & 23,062 & 36 & 37 \\
\hline Huntingdon & 15,541 & 10,118 & 65 & 100 \\
\hline Juniata & 7,583 & 5,364 & 70 & 100 \\
\hline Lancaster & 151,352 & 50,966 & 33 & 100 \\
\hline Lebanon & 42,708 & 13,034 & 30 & 85 \\
\hline Mifflin & 17,737 & 6,729 & 37 & 100 \\
\hline Northumberland & 38,789 & 9,482 & 24 & 62 \\
\hline Perry & 14,930 & 11,112 & 74 & 100 \\
\hline Schuylkill & 60,690 & 14,685 & 24 & 41 \\
\hline Snyder & 12,697 & 6,913 & 54 & 100 \\
\hline Somerset & 29,592 & 11,228 & 37 & 3 \\
\hline Union & 11,614 & 6,178 & 53 & 28 \\
\hline York & 128,764 & 43,441 & 33 & 100 \\
\hline TOTALS & $1,574,279$ & 486,372 & & \\
\hline
\end{tabular}




\section{Purpose and Scope}

This report describes and explains the bacteriological quality of raw water from private wells used for household water supplies in the Lower Susquehanna River Basin study unit. The results are based on samples collected by the NAWQA Program in 1993-95 from 146 wells in 17 counties in Pennsylvania and 2 counties in Maryland. Ground-water samples were analyzed for concentrations of total coliform, fecal coliform, Escherichia coli $(E$. coli), and fecal streptococcus.

\section{Bacteria and Potability of Ground Water}

Bacterial, viral, and protozoan pathogens are among the most dangerous contaminants in drinking water. About 50 percent of the waterborne disease outbreaks in this country since the early 1900's were caused by contaminated ground water that was untreated or inadequately treated. Most outbreaks were caused by pathogenic (disease-causing) microorganisms (Yates and Yates, 1993).

Water sources that are free from disease-causing impurities and other harmful substances are said to be potable water sources. Potable water is water fit for human consumption. Public water supplies that have passed State potability standards must not have impurities in amounts above maximum contaminant concentrations that have been set by the State or the U.S. Environmental Protection Agency (USEPA). Each State has its own criteria defining the potability of water.

Bacterial potability of water is determined by testing for indicator organisms. Indicator organisms are bacteria whose presence in drinking water indicates that pathogens may be present (Gabler and others, 1988). Indicator organisms are easier to detect and test for than the pathogens themselves; therefore, analysis for the presence of indicator organisms is the method of choice in testing for potable water supplies. The indicator bacteria were the coliform bacteria group and the streptococcal bacteria group. The presence of $E$. coli in ground water indicates that the contamination of the water supply is fecal in origin. $E$. coli originates in the feces and intestines of warm-blooded animals (Bordner and others, 1978; American Public Health Association and others, 1992). Sources of fecal-indicator bacteria include septic system failure or improper septic system construction or design, feedlot or field runoff, manure application on fields, and application of municipal sludge. The presence of total coliform, fecal coliform, or fecal streptococcus indicates that the contamination of the water supply is fecal in origin, but these bacteria types do not exist solely in the feces of warm-blooded animals. Total coliform, fecal streptococcus, and, to some extent, fecal coliform also are present in some soils, for example.

A common misconception is that untreated ground water is generally safe for consumptive use and that most contaminants are removed as the water filters down through the soil. The soil does act as a natural filter for water percolating down through the ground, but this does not guarantee that ground-water supplies cannot become contaminated. Ground-water supplies are subject to bacterial contamination. Water from wells used for potable supply should be routinely tested to ensure that contamination has not occurred. 


\section{Regulations for Private Wells in Pennsylvania and Maryland}

Water samples were collected from wells in Pennsylvania and Maryland. With the exception of regulations in selected counties with health departments, no public health regulations exist for the permitting and inspection of private wells in most of Pennsylvania (Michael E. Moore, Pennsylvania Department of Conservation and Natural Resources, oral commun., 1995). In the study unit, wells in Chester County, Pa., and in Maryland are permitted and inspected by county health departments. The differences in the drilling of wells for private water supplies in the two states are described below. The significance of these differences on the bacteriological quality of the water samples collected could not be evaluated because only four samples were collected in Chester County, Pa., and six samples were collected in Maryland.

Pennsylvania currently has no statewide well-construction regulations. Well drillers are required by law (Act 610) to obtain certification through the Pennsylvania Department of Conservation and Natural Resources, Bureau of Topographic and Geologic Survey (Commonwealth of Pennsylvania, 1976). The certifying state agency does not have the authority to regulate well-construction practices. In Chester County, Pa., the health department requires permit applications for installation of wells to be filed by a Chester County licensed well contractor. An approval to use water from the permitted well is issued only after submission of properly completed forms and reports. A report on water quality is required and must certify that the water meets numerous standards including a total coliform concentration of less than one colony per $100 \mathrm{~mL}$ (Ralph DeFazio, Chester County Health Department, oral commun., 1996). The requirements for Chester County are atypical, and the vast majority of wells in the Lower Susquehanna River Basin of Pennsylvania are sited and drilled with no regulatory oversight.

Maryland has regulations for the construction of wells to be used as individual potable water supplies. Well drillers must be licensed by the Maryland State Board of Well Drillers and are required to submit well-permit applications that contain the proposed well-construction and location specifications to the Approving Authority. The Approving Authority is the Secretary of the Environment or a designee appointed by the Secretary of the Environment (Maryland Code (COMAR) 26.04.04.02.B). Wells must pass Maryland's definition of a "potable water source." Adherence to well-location standards (COMAR 26.04.04.05.B(2)), well-construction standards (COMAR 26.04.04.07), and wellabandonment standards is a prerequisite for approval of the well as a potable water source. Disinfection procedures must be followed upon completion of the well (COMAR 26.04.04.07. N(5)), and a certificate of potability must be obtained (COMAR 26.04.04.09). Wells are inspected for physical defects, and maximum contaminant concentrations have been set for bacteriological and chemical constituents (COMAR 26.04.01). The maximum contaminant concentration for total coliform is zero colonies per $100 \mathrm{~mL}$ (Woody Williams, Harford County Health Department, oral commun., 1995). In other words, total coliforms must not be detected in the water sample collected from the well for a certificate of potability to be issued. 


\section{Previous Investigations}

Previous studies attempting to quantify the bacteriological quality of ground water have been conducted on private individual water supplies. Three studies of private well water supplies are summarized here: one in Pennsylvania; one in Ohio; and one national study.

A study was conducted by The Pennsylvania State University (Sharpe and others, 1985) in which ground-water-quality data were collected from all regions of Pennsylvania from 1974 to 1983 . The samples were collected from 268 private individual water systems, including about 200 wells, where water-quality problems were perceived to exist. Analyses were conducted for several water-quality constituents including total coliform bacteria. Approximately 40 percent of the private water-supply systems, both wells and springs, had bacterial contamination. Spring water-supply sources were more frequently contaminated with bacteria than well water sources.

A study in northwestern Ohio (Breen and Dumouchelle, 1991) was conducted by the USGS, in cooperation with county and municipal agencies, from 1985 to 1988 to evaluate the hydrology and quality of ground water. Bacteriological tests of water from 141 wells completed in carbonate aquifers were conducted. Total coliforms were present in more than 50 percent of the collected samples, and fecal coliforms were present in approximately 20 percent. Nearly 40 percent of the collected samples tested positive for fecal streptococcus bacteria. Fecal streptococcus was present in approximately two-thirds of the samples that had total coliform bacteria and approximately 70 percent of the samples that had fecal coliform bacteria.

Another study conducted on a broader scale and led by Cornell University (Francis and others, 1984) was a national assessment of the water quality of rural domestic water supplies in northeast, north central, south, and west regions of the United States from May 1978 through January 1979. Total coliform, fecal coliform, and fecal streptococcus bacteria types were among constituents tested. The results summarized here refer to testing conducted in intermediate (several households supplied by the same well) and individual water systems. About 90 percent of the households with individual systems and about 88 percent of the households with intermediate systems relied on wells. The remaining households relied on cisterns, springs, surface water, hauled, or purchased bottled water. More than 40 percent of the waters from intermediate or individual systems had total coliforms. Fecal coliforms were present in 20 percent of the intermediate or individual systems and fecal streptococcus was present in 19 percent of all rural water-supply systems in which testing was conducted. A breakdown of the percentage of fecal streptococcus present in intermediate or individual water systems was not given. 


\section{Description of the Study Area}

The Lower Susquehanna River Basin study unit drains $9,200 \mathrm{mi}^{2}$, extending from Sunbury, Pa., downstream to the Chesapeake Bay, Md., and includes the Northeast River drainage basin (fig.1). About 47 percent of the study unit is forested, and agricultural land use comprises another 47 percent of the area (Risser and Siwiec, in press). Water samples were collected in the following five study areas: (1) agricultural areas underlain by limestone and dolomite bedrock in the Piedmont Physiographic Province, (2) areas underlain by sandstone and shale in the Appalachian Mountain Section of the Ridge and Valley Physiographic Province, (3) areas underlain by igneous and metamorphic rocks (hereafter termed crystalline bedrock) in the Piedmont Physiographic Province, (4) agricultural areas underlain by limestone and dolomite bedrock in the Appalachian Mountain Section of the Ridge and Valley Physiographic Province, and (5) agricultural areas underlain by limestone and dolomite bedrock in the Great Valley Section of the Ridge and Valley Physiographic Province. The areas underlain by limestone and dolomite are referred to as carbonate subunits in this report. The areas, hereafter termed environmental subunits, are described in table 2 and are shown in figure 1.

\section{Acknowledgments}

The authors wish to express their thanks to all the homeowners who kindly permitted the sampling of their private water wells. This manuscript was prepared with the assistance of a report team that included Paul Stackelberg, Donna Francy, Dennis Risser, Kevin Breen, Steven Siwiec, Kim Wetzel, Charles Wood, James Gerhart, and Russell Ludlow of the U.S. Geological Survey, Stuart Reese of the Pennsylvania Department of Environmental Protection, and Woody Williams of the Harford County Health Department in Maryland. The authors thank the team for contributing their knowledge and expertise throughout all stages of the report-writing process. 


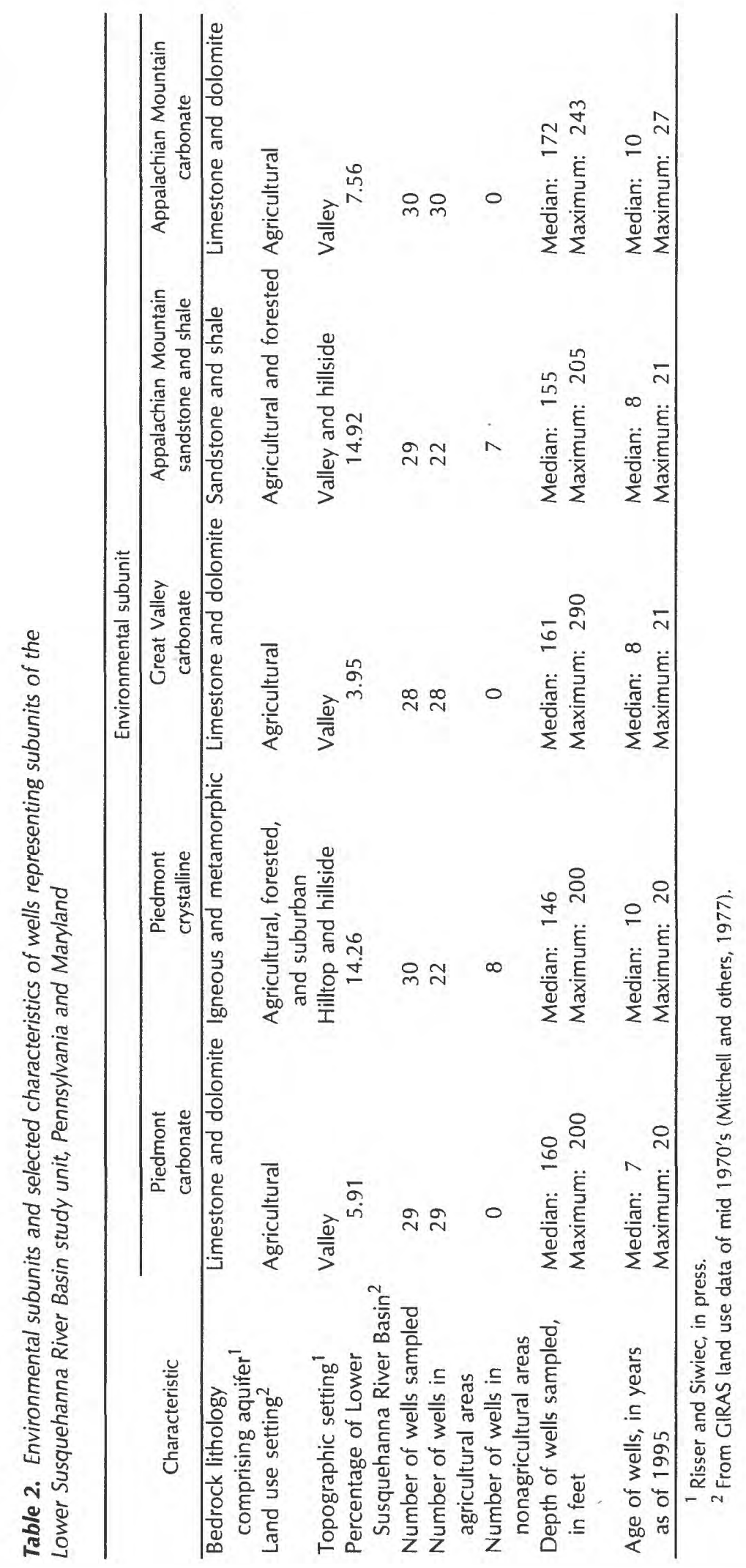



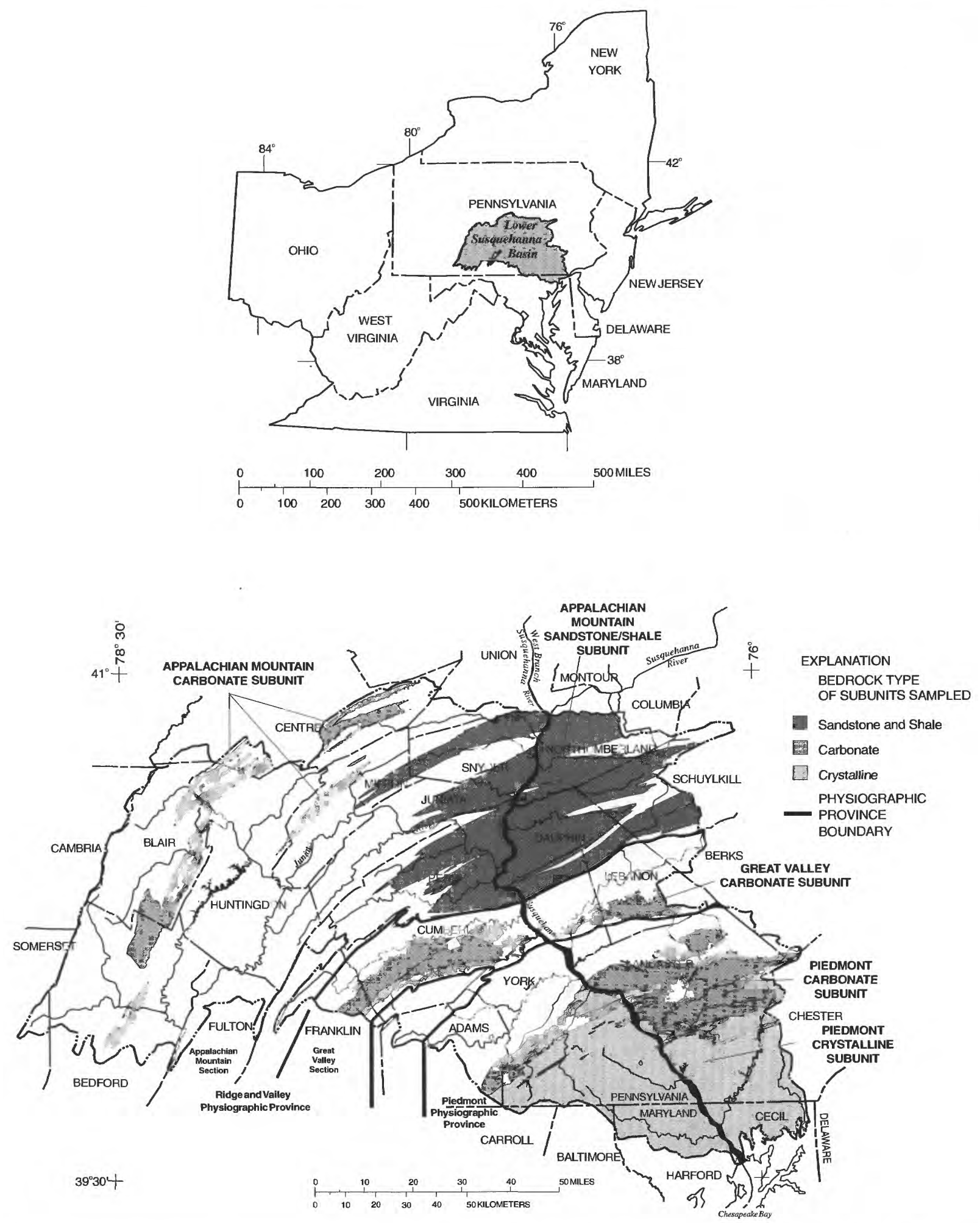

Figure 1. Location of environmental subunits sampled and bedrock types, Lower Susquehanna River Basin study unit, Pennsylvania and Maryland. 


\section{METHODS OF STUDY}

Water samples were collected for bacteriological testing during three summer seasons: July 8, 1993, through August 11, 1993, in the Piedmont carbonate and the Appalachian Mountain sandstone and shale subunits; June 28, 1994, through August 16, 1994, in the Piedmont crystalline and the Appalachian carbonate subunits; June 26, 1995, through August 9, 1995, in the Great Valley carbonate subunit. Water from each of the 146 wells from these five subunits was sampled once for this study. The wells were chosen on the basis of both subunit criteria and construction criteria. Owner permission to use the well was an additional criterion.

Subunit criteria included the physiographic province, bedrock type, and land use. Subunit boundaries were established with a geographical information system (GIS). A computerized random-selection program was then used to select potential sampling locations within each subunit (Scott, 1990). Field visits were conducted to confirm landuse criteria, and the bedrock type was confirmed by geologic maps and drilling records. Sites were chosen such that there were no feedlots within a half mile radius.

Once a potential sampling location was selected, homeowners were queried and drilling records were checked to determine if their well met the well-construction criteria. The well-construction criteria were established to obtain samples representative of shallow ground water. These criteria dictated that the wells were open boreholes, drilled and completed in the bedrock, less than $200 \mathrm{ft}$ deep, and less than 25 years old. Most wells sampled met all of the sampling criteria; in few cases where these criteria could not be met, deeper or older wells were sampled (table 2). All wells sampled had similar household plumbing designs. A detailed plumbing inspection ensured that the sample was raw water. Most samples were collected from an outside faucet on the house. Because it was not possible to fill the bottles directly under the spigot in many cases, a Teflon sampling hose was used to fill the sample bottles. If a raw water spigot was not available outside the house, the Teflon sampling hose was connected directly to a spigot at the pressure tank. The sampling hose was cleaned with a Liquinox soap solution and rinsed with $5 \mathrm{gal}$ of deionized water between sites. Hoses were not autoclaved or disinfected; the amount of water that passed through the hose prior to sampling was 100 to 300 gal.

A minimum of one well volume of water was purged prior to sampling. The well volume was estimated from the static water level, the casing diameter, and the total depth of the well. Latex gloves were worn during sample collection. Water samples for bacteriological analyses were collected in 1-L, amber-colored, glass bottles that had been sterilized at $121^{\circ} \mathrm{C}$ and $15 \mathrm{psi}$ for 15 minutes in an autoclave. The samples of untreated ground water were collected in a plastic enclosure designed to reduce the risk of airborne contaminants entering the sample bottles. Water samples were kept on ice until they were processed for analysis. 


\section{Microbiology}

Water samples were analyzed for concentrations of indicator bacteria of two taxonomic groups. Total coliform, fecal coliform, and $E$. coli are members of the coliform group. E. coli are a subset of fecal coliforms and fecal coliforms are a subset of total coliforms. Total coliforms are those organisms that produce a golden-green metallic sheen within 24 hours on m-Endo media when incubated at $35^{\circ} \mathrm{C}$. Fecal coliforms are organisms that produce blue colonies within 24 hours on $\mathrm{m}-\mathrm{FC}$ media when incubated at $44.5^{\circ} \mathrm{C}$. E. coli are organisms that produce a bright blue fluorescent perimeter around a darker colony center within 4 hours when incubated at $35^{\circ} \mathrm{C}$ on NA-MUG media after primary culturing as total coliform bacteria on $\mathrm{m}$-Endo media. The fecal streptococcus group also was studied and is defined as all organisms that produce red or pink colonies within 48 hours on $\mathrm{KF}$ media when incubated at $35^{\circ} \mathrm{C}$. A summary of processing methods is given in table 3.

All water samples were processed by use of membrane filtration techniques within 6 hours of collection (Britton and Greeson, 1989); most samples were processed within 1 hour. From the 1-L sample of ground water, $100-\mathrm{mL}$ aliquots were measured in sterilized, glass graduated cylinders. The aliquots were filtered with a hand-operated vacuum pump through 0.45 or $0.65 \mu \mathrm{m}$ pore-size membrane filters mounted in sterilized plastic funnels. The membrane filters were placed on the media in petri dishes. The petri dishes were immediately placed into incubators in an inverted position.

Table 3. Summary of sample processing methods for determination of bacterial concentrations in well water

\begin{tabular}{|c|c|c|c|}
\hline Bacteria type & Media type & Processing method & Reference \\
\hline Total coliform & m-Endo & $\begin{array}{l}\text { membrane filtration }(0.45 \mu \mathrm{m}) \\
\text { immediate incubation }\end{array}$ & $\begin{array}{c}\text { Britton and Greeson } \\
(1989, \text { p. 13-16) }\end{array}$ \\
\hline Fecal coliform & $m-F C$ & $\begin{array}{l}\text { membrane filtration }(0.65 \mu \mathrm{m}) \\
\text { immediate incubation }\end{array}$ & $\begin{array}{c}\text { Britton and Greeson } \\
(1989, \text { p. 37-40) }\end{array}$ \\
\hline E. coli & NA-MUG & $\begin{array}{l}\text { membrane filtration }(0.45 \mu \mathrm{m}) \\
\text { First incubate on m-Endo media } \\
\text { for } 24 \text { hours, and then transfer } \\
\text { to NA-MUG media }\end{array}$ & $\begin{array}{l}\text { U.S. Environmental Protection } \\
\text { Agency }(1991, \text { p. 1) }\end{array}$ \\
\hline Fecal streptococcus & KF & $\begin{array}{l}\text { membrane filtration }(0.45 \mu \mathrm{m}) \\
\text { immediate incubation }\end{array}$ & $\begin{array}{c}\text { Britton and Greeson } \\
(1989, \text { p. 47-50) }\end{array}$ \\
\hline
\end{tabular}




\section{Quality Assurance}

Quality-assurance measures were practiced throughout the study. All samples tested for bacteria were processed and analyzed by USGS personnel from the Pennsylvania District Office in Lemoyne, Pa. The effectiveness of sterilization procedures was checked by processing a sterile-water blank at each sampling site. Water used for the blanks was a sterile phosphate buffer solution with peptone. Instructions on how to prepare buffered dilution water are found in Britton and Greeson $(1989$, p. 18). Blanks were $30 \mathrm{~mL}$ of sterile buffered water that were processed with the sterilized equipment before the sample water was processed. If colonies formed on the blank plates, the corresponding site sample results were disregarded. This occurred one time for fecal streptococcus out of 438 blank plates for total coliform, fecal coliform, and fecal streptococcus. Duplicate samples were filtered and analyzed for each bacteria type at each site. The average bacteria colony count of the two plates was recorded. If either of the plates was unreadable, the colony count from the remaining plate was recorded.

Because the sampling hose was not sterilized, and no blanks were collected through the sampling hose, the data were analyzed to determine if cross-contamination from site to site could have occurred. All detections were compared to the detections at the previous site. At 67 percent of the sites, cross contamination was not possible because either the previous site or the following site had no detections of bacteria. At an additional 11 percent of the sites, cross contamination was highly unlikely because a high bacteria count was preceded by a low bacteria count. At the remaining sites it is numerically possible that cross contamination occurred, because a low bacteria count was preceded by an equal or higher bacteria count. It is considered to be very unlikely that this occurred because of the cleaning of the hose and the large volume of water (100 to $300 \mathrm{gal})$ that passed through the hose before the sample was collected. Also, at 16 percent of the sites, a detection of bacteria was followed by a nondetection of bacteria, which indicates the effectiveness of the cleaning process in those cases.

All sample media and sterile buffered water were obtained from the Quality of Water Service Unit (QWSU) in Ocala, Fla. The bacteria kits that QWSU supply must pass quality-assurance tests performed by the USGS National Water Quality Laboratory (Horowitz and others, 1994). All media were fresh and used prior to the expiration date. 


\section{Statistics}

Statistical tests were selected to determine 1) relations between concentrations of bacteria and categorical variables such as land use or lithology and 2) relations between concentrations of bacteria and continuous variables such as well depth or nitrate concentrations. Histograms and Wilk-Shapiro tests were used to determine the normality of the distribution of the bacterial concentrations. The data are not normally distributed. Therefore, nonparametric statistical methods were used to analyze the data. The degree of censoring was quantified by determining the percentage of nondetects for each bacteria type. Some data also are censored at an upper detection limit (>80 colonies/100 mL) because dilutions were not conducted.

The Kruskal-Wallis test was used to make comparisons in the ranks of concentrations of bacteria between categorical variables. This tests for differences in the mean ranks of two or more groups. If the Kruskal-Wallis tests on the entire population showed significant differences among categories, a Multi-Stage Kruskal-Wallis (MSKW) test was performed on the ranked data to show how the categories differed with an overall alpha value of 0.05 . A probability was calculated for each statistical test conducted. If the probability is less than the alpha value $(0.05)$ for the Kruskal-Wallis test, there is a 95 percent probability that categories are significantly different, or less than 5 chances out of 100 that the categories being tested are from the same population. This test was used on data sets in which less than 50 percent of the data were below the detection limit, which included the total coliform and fecal streptococcus data sets.

If more than 50 percent of the data are censored, the nonparametric tests based on ranks have less power to detect differences in central tendencies (Helsel and Hirsch, 1992 , p. 367). In these cases, the response variable, bacteria, was converted to a categorical variable (detect/nondetect). The Kruskal-Wallis test was then used to test for a shift in the distribution of detects and nondetects instead of testing for differences in the medians of continuous data. (Helsel and Hirsch, 1992, p. 382). If significant differences existed for the categories, MSKW tests were performed on the subcategories to determine which subcategories differed, again with the overall alpha value being set equal to 0.05 . This test was used for the fecal coliform and $E$. coli data sets. Categories that were not significantly different were assigned a common letter code (tables 4-7) Categories could be assigned more than one letter.

Spearman's rank correlation was used to test for correlations between concentrations of bacteria and other continuous variables. This test is a nonparametric measure of the monotonic relation between two continuous variables. In this test, bacterial concentrations are ranked and compared with other ranked numerical variables. Monotonic relations may be nonlinear but show an association between the two variables tested. An alpha of 0.05 was used in the analyses. If the probability from Spearman's correlation test is less than alpha, there is a 95 percent chance that an association exists mathematically between the variables. Spearman's rho is used to determine the strength of this association. A small Spearman's rho means that the correlation is poor and that the correlation may not be practically significant-of any use in predicting one variable from the other (Dennis Helsel, U.S. Geological Survey, written commun., 1995). 


\section{BACTERIOLOGICAL QUALITY OF GROUND WATER USED FOR HOUSEHOLD SUPPLY}

Public health standards that define the potability of water have been set by the USEPA for the microbiological quality of drinking water used for public water supply. These standards use total coliform as the indicator bacteria for public drinking water supplies (U.S. Environmental Protection Agency, 1994). No national standards have been set for private, individual water supplies, therefore, USEPA's public supply standards are used in this report for comparison purposes only. The health effects of the presence of even one fecal coliform bacterium in a 100-mL sample of drinking water is viewed with concern by public health authorities (Francis and others, 1984).

The data for bacteriological testing in the Lower Susquehanna River Basin study unit are listed in the USGS annual water data reports for the 1993-94 water years (Durlin and Schaffstall, 1994; 1996). The 1995 data used for analysis can be obtained from the USGS office in Lemoyne, Pa.

Total coliform, fecal coliform, and fecal streptococcus bacteria were not found in water samples from 31 of the 146 wells tested. Nearly 70 percent of the 146 water samples were positive for total coliform bacteria (fig. 2), and nearly 25 percent of the samples that were positive were too numerous to count (fig. 3). Approximately 25 percent of the samples were positive for fecal coliform bacteria (fig. 2), and nearly 15 percent of the samples that were positive were too numerous to count (fig. 3). These percentages are higher than those found in previous studies. Approximately 65 percent of the water samples were positive for fecal streptococcus bacteria (fig. 2), and almost 35 percent of the samples that were positive were too numerous to count (fig. 3 ).

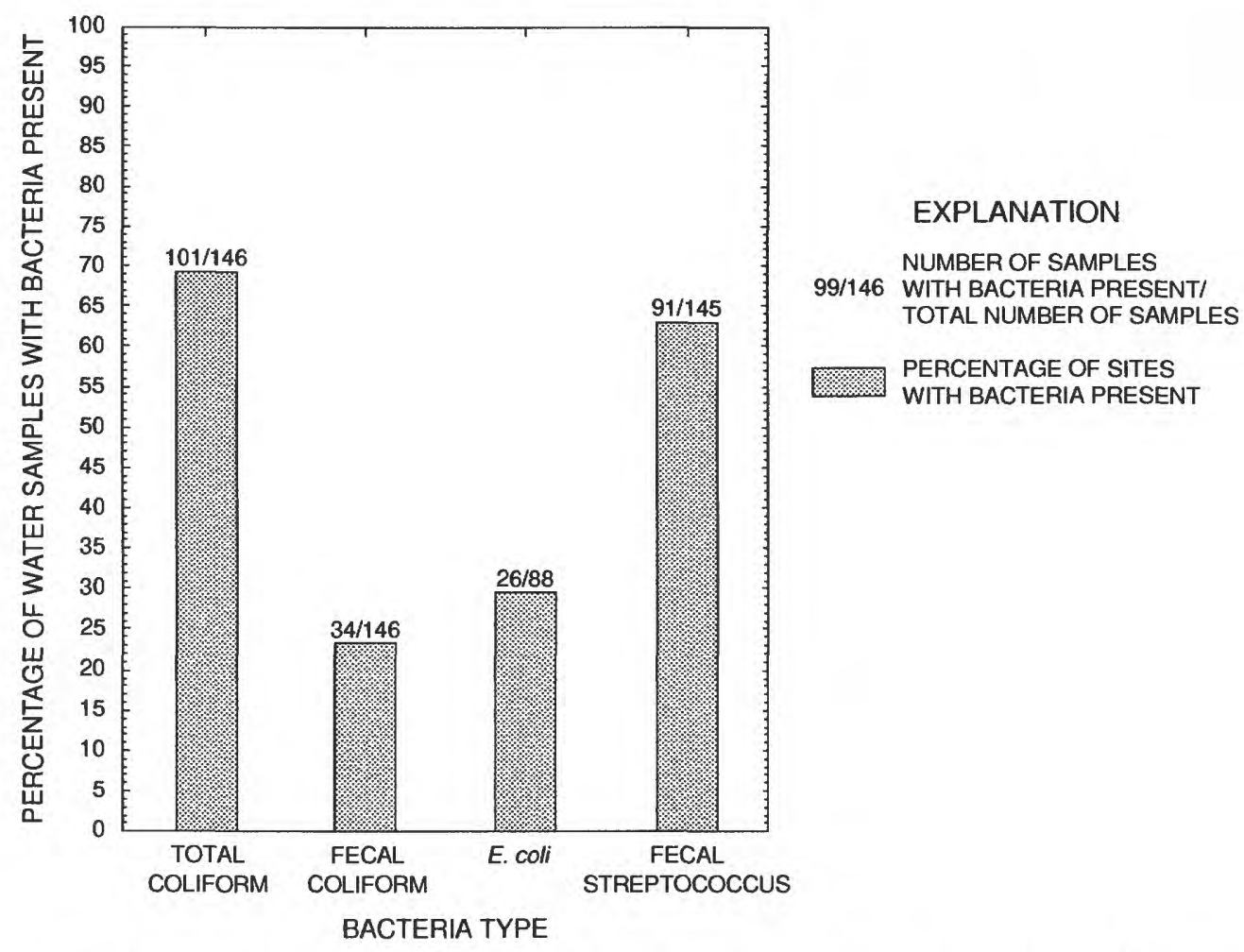

Figure 2. Bacteria presence in ground water from wells sampled as part of the National WaterQuality Assessment in the Lower Susquehanna River Basin study unit, Pennsylvania and Maryland. 


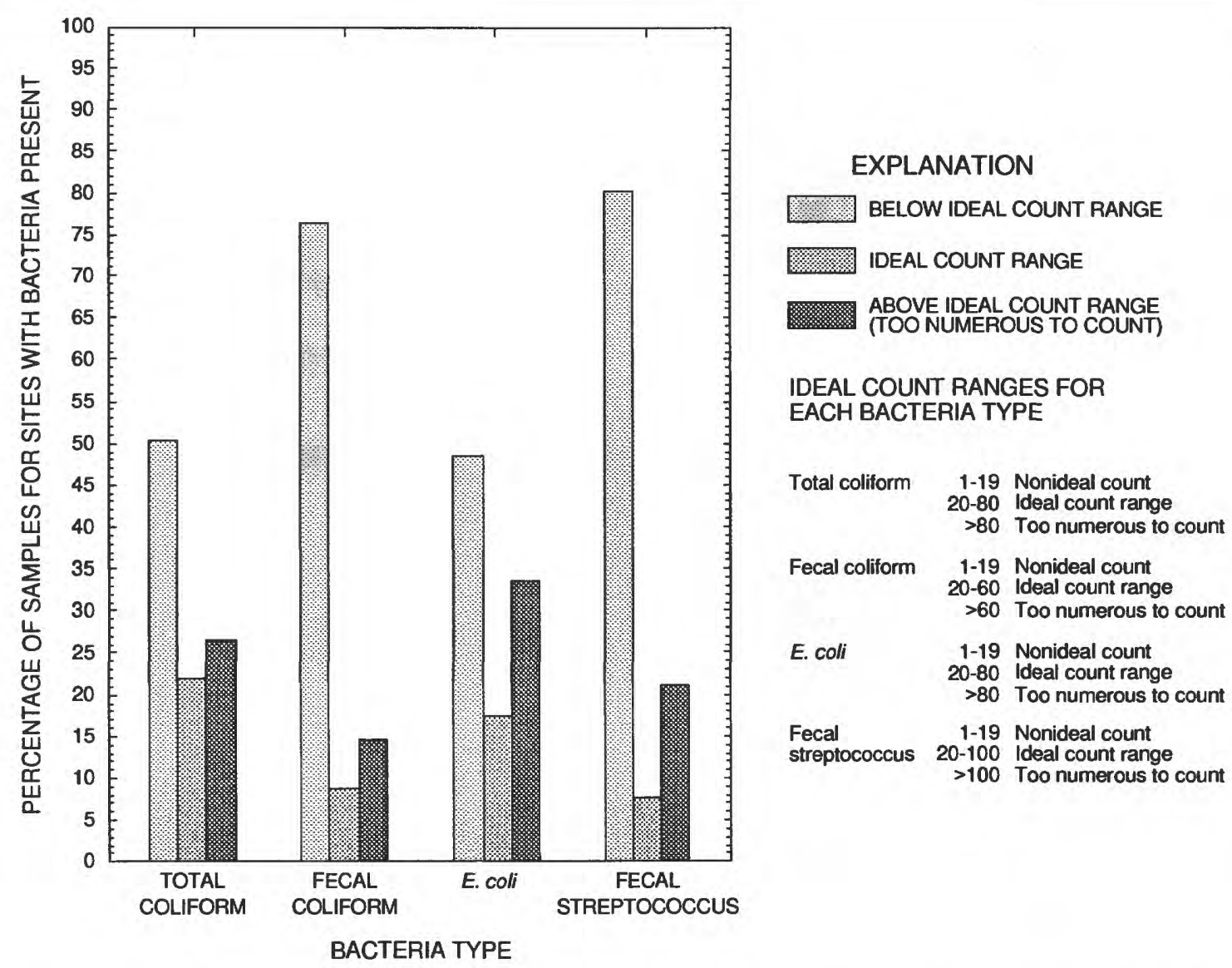

Figure 3. Distribution of bacteria among count ranges in ground water from wells sampled as part of the National Water-Quality Assessment in the Lower Susquehanna River Basin study unit, Pennsylvania and Maryland.

E. coli testing was not conducted during 1993, the first year of the Lower Susquehanna River Basin study. Therefore, only 88 of the 146 water samples were tested for $E$. coli. About 30 percent of the samples from those 88 wells were positive for $E$. coli bacteria (fig. 2), and more than 10 percent of the samples that were positive were too numerous to count (fig. 3). The percentage of $E$. coli detections is higher than the percentage of fecal coliform detections (fig. 2). This is due to the fact that $E$. coli testing was only conducted on 88 of the 146 water samples.

Approximately one-third of the samples that contained total coliform bacteria also contained fecal coliform bacteria, a percentage that agrees with the data of Breen and Dumouchelle (1991). Fecal streptococcus bacteria were present in more than threequarters of the samples that tested positive for total coliform bacteria and in all of the samples in which fecal coliform bacteria was present.

The distribution of wells sampled in the Lower Susquehanna River Basin and the presence of total coliform and fecal coliform are shown in figures 4 and 5, respectively. Total coliform detections are distributed relatively evenly over all of the areas studied. The distribution of detections of fecal coliform, however, shows a more clustered pattern with almost one-half of the detections of fecal coliform being in the Great Valley carbonate subunit. 


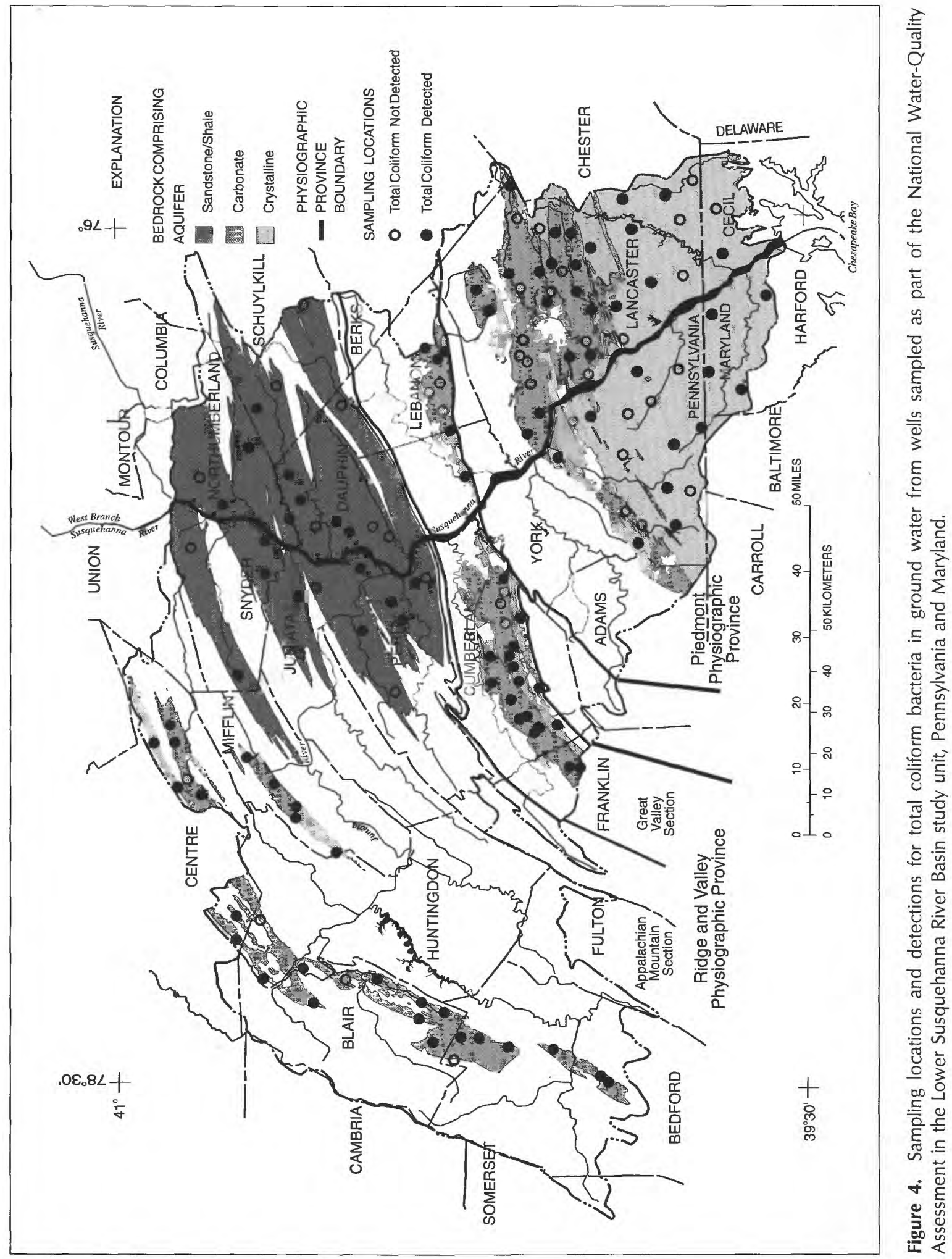




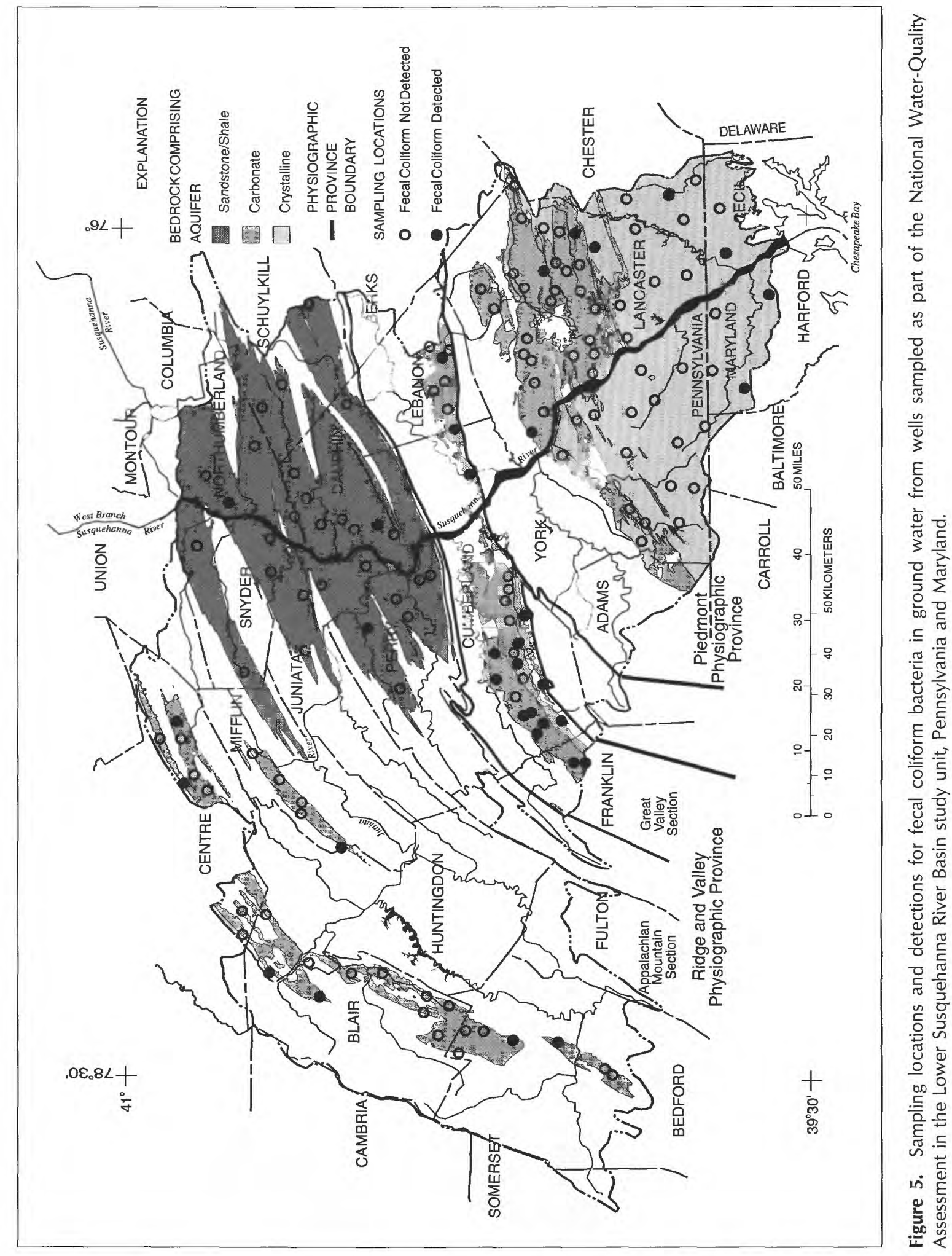


The Great Valley carbonate and Appalachian Mountain carbonate subunits had the highest percentages of the presence of bacteria (fig. 6). Fecal coliform and $E$. coli distributions shown in figure 6 are similar, as would be expected because $E$. coli is a subset of fecal coliform. The similarity between the distributions of total coliform and fecal streptococcus shown in figure 6 suggests that both of these bacteria types may originate from the same sources. The data were analyzed to determine variations in the concentrations of bacteria among environmental subunits, to determine relations between bacterial concentrations and well characteristics, and to determine relations between concentrations of bacteria and other water-quality constituents.
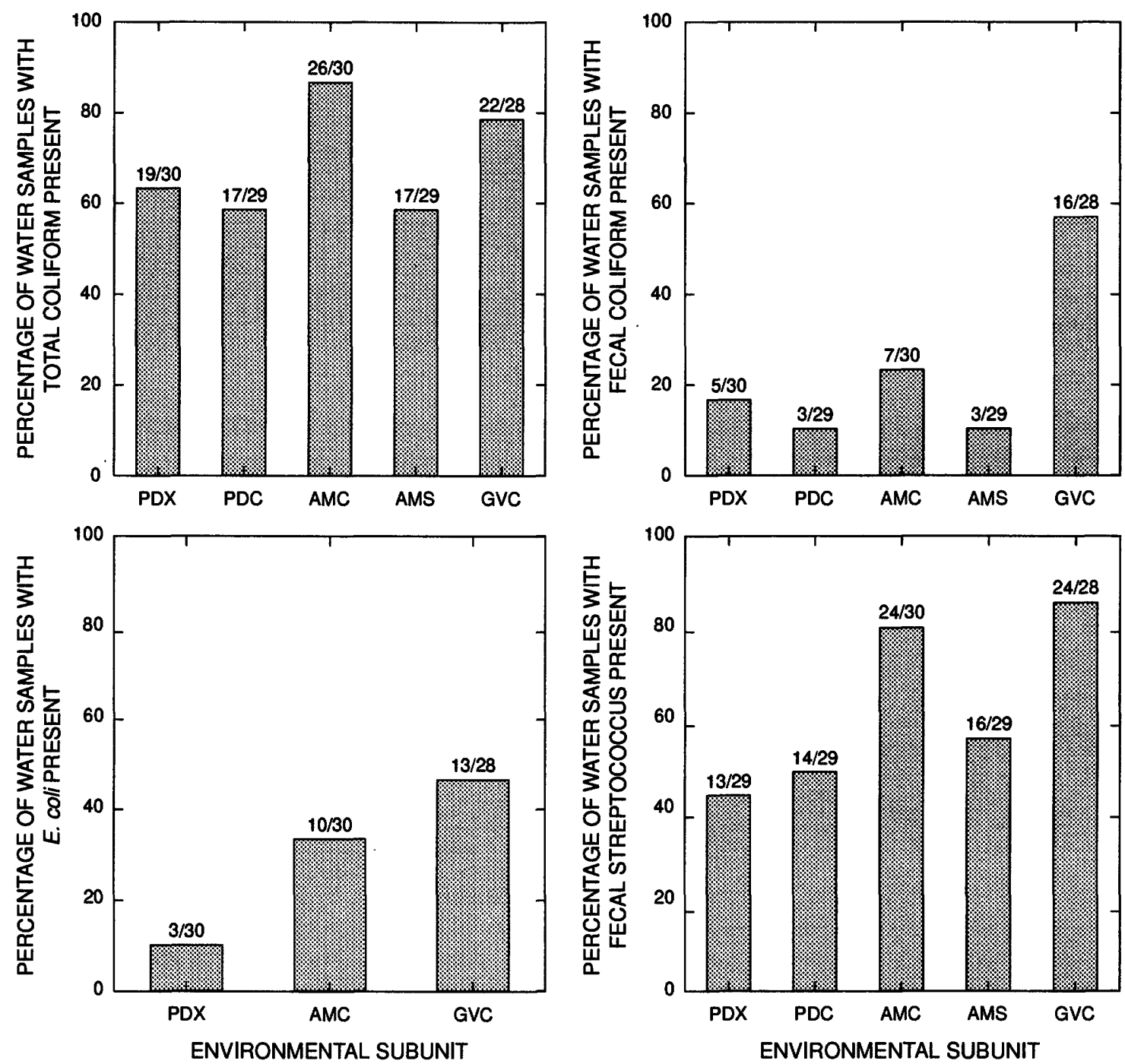

\section{EXPLANATION}

PDX - Piedmont crystalline subunit PDC - Piedmont carbonate subunit

AMC - Appalachian Mountain carbonate subunit

AMS - Appalachian Mountain sandstone and shale subunit

GVC - Great Valley carbonate subunit

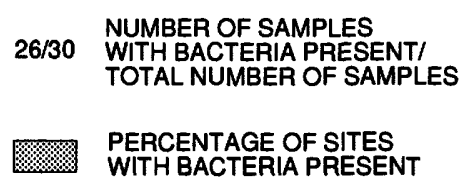

Figure 6. Presence of total coliform, fecal coliform, E. coli, and fecal streptococcus as a percentage of the number of wells sampled in each environmental subunit in the Lower Susquehanna River Basin study unit, Pennsylvania and Maryland. 


\section{Relations Between Bacterial Concentrations and Land Use, Physiography, and Lithology}

Statistical tests were conducted to determine if relations existed between bacterial concentrations and land use, physiography, and bedrock lithology comprising the aquifer. Testing the variation in bacterial concentrations among land-use categories was conducted because manure is applied to cropland and pastures in agricultural areas providing an additional source of bacteria that is not present in nonagricultural areas. Comparisons of bacterial concentrations to bedrock lithology help determine if certain types of aquifers are more susceptible to bacteria contamination than others. Statistical tests also were conducted to determine if the combination of land use, lithology, and physiography was a significant factor affecting bacterial concentrations.

For land-use relations, bacterial concentrations in agricultural and nonagricultural areas were compared. Boxplots show that total coliform and fecal streptococcus have a broader range of concentrations and higher median values in agricultural areas than in nonagricultural areas (fig. 7). Statistical tests showed significant differences among land-use categories for total coliform, fecal coliform, and fecal streptococcus (table 4). Although the differences between land-use categories are not statistically significant for $E$. coli at the selected 95-percent confidence level, the probability is very close to the level that would indicate significant differences existed between land-use categories. The data and statistics shown in figure 7 and table 4 indicate that higher bacterial concentrations are related to agricultural land use. Boxplots for fecal coliform and E. coli are not presented because of the small percentage of sites where those bacteria types were detected.

Physiographic province also is related to bacterial concentrations. Boxplots show that all four bacteria types have higher median concentrations and broader ranges of concentrations in the Ridge and Valley Physiographic Province than in the Piedmont Physiographic Province (fig. 8). The statistical test results also indicate significant differences between the physiographic provinces for all of the bacteria types (table 5). Equal numbers of agricultural and nonagricultural wells were sampled in both provinces. Moreover, a similar number of wells completed in carbonate and noncarbonate bedrock were sampled in both provinces. This variation in bacteriological quality of water by physiographic province could not be explained and could be related to regional variation in well characteristics, socioeconomic conditions, siting of septic systems, or agricultural practices (Francis and others, 1984).

Bedrock lithology comprising the aquifer also was evaluated as a factor related to bacterial concentrations. Boxplots show that total coliform and fecal streptococcus have a broader range of concentrations and higher median values in areas underlain by carbonate bedrock than in areas underlain by other bedrock types (fig. 9). Previous studies have shown that ground water is more susceptible to contamination by nitrate and herbicides in areas underlain by carbonate bedrock than in areas underlain by noncarbonate bedrock (Fishel and Lietman, 1986). Water from carbonate bedrock has the highest mean rank of bacterial concentrations for all of the bacteria types; however, statistical tests show that the differences among the mean ranks for bedrock lithology categories are not statistically significant for total coliform, fecal coliform, or fecal streptococcus at the 95-percent confidence level (table 6). The probabilities for fecal coliform $(0.065)$ and total coliform $(0.070)$ are both close to the 0.05 level that would indicate significant differences among lithology categories for these bacteria types. Apparent differences shown for $E$. coli among categories could be because of the fact that $E$. coli samples were only analyzed in two of the lithology categories. The data and statistics shown in table 7 and figure 10 indicate that some differences exist among lithology categories; higher concentrations of bacteria are detected in areas underlain by carbonate bedrock. This relation is not statistically significant for all bacteria types.

The land-use setting within the environmental subunit was evaluated to determine the combined effects of land use, physiography, and lithology on bacterial concentrations. Combining land use, physiography, and lithology specifically identifies areas where bacterial concentrations are highest. Boxplots show that the broadest range of concentrations and the highest medians for total coliform and fecal streptococcus are in the Appalachian Mountain and Great Valley carbonate agricultural settings (fig. 10). The Appalachian 
Mountain and the Great Valley carbonate agricultural settings are both in the Ridge and Valley Physiographic Province (table 1). Statistical analyses showed significant differences among settings for every bacteria type (table 7). The Appalachian Mountain carbonate and Great Valley carbonate agricultural settings consistently had the highest mean ranks. Nonagricultural settings in the Piedmont crystalline subunit consistently had the lowest mean ranks.

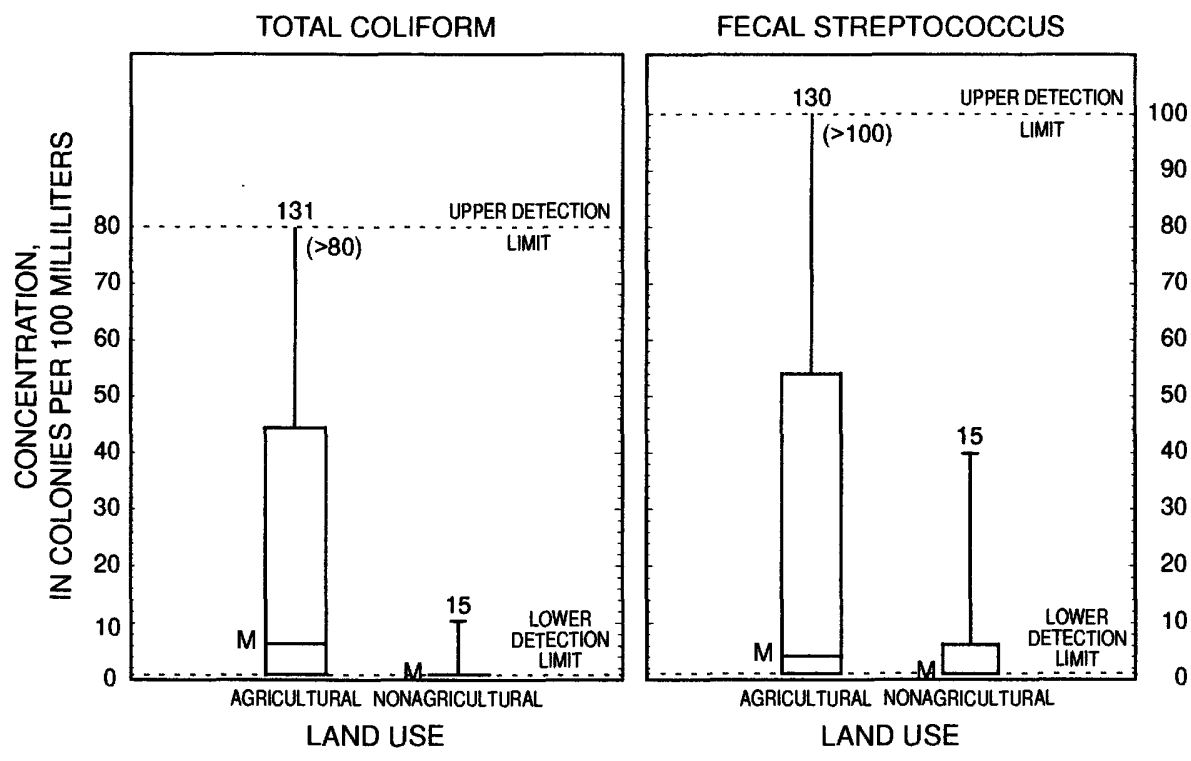

EXPLANATION

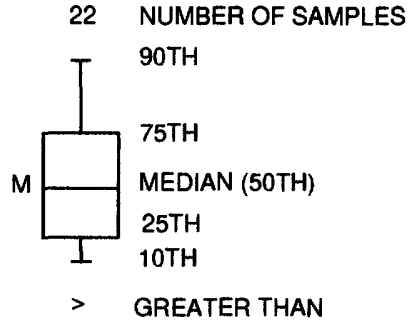

PERCENTILE - Percentage of analyses equal to or less than indicated values. If plot truncated at top, percentiles exceed upper detection limit.

Note: Plates with no colonies are reported as less than one colony per $100 \mathrm{~mL}$; therefore, the lower detection limit is one colony per $100 \mathrm{~mL}$. Plates with more than 80 total coliform colonies or 100 fecal streptococcus colonies were considered too numerous to count and reported as greater than 80 or greater than 100 colonies per $100 \mathrm{~mL}$, respectively. This is the upper detection limit for total coliform and fecal streptococcus.

Figure 7. Distribution of concentrations of total coliform and fecal streptococcus among land-use types, Lower Susquehanna River Basin study unit, Pennsylvania and Maryland.

Table 4. Results of statistical analyses for relations between land use and bacterial concentrations, Lower Susquehanna River Basin study unit, Pennsylvania and Maryland

[Values followed by the same letter are not significantly different as determined by Kruskal-Wallis Tests.]

\begin{tabular}{lcc}
\hline \multirow{2}{*}{ Probability } & \multicolumn{2}{c}{ Mean rank } \\
\cline { 2 - 3 } & Agricultural & Nonagricultural \\
\hline$\frac{\text { Total coliform }}{0.002}$ & $77-\mathrm{A}$ & $41-\mathrm{B}$ \\
$\frac{\mathrm{Fecal} \text { coliform }}{.026}$ & $75-\mathrm{A}$ & $57-\mathrm{B}$ \\
$\frac{\text { E. coli }}{.059}$ & $45-\mathrm{A}$ & $31-\mathrm{A}$ \\
$\frac{\text { Fecal streptococcus }}{.028}$ & $75-\mathrm{A}$ & $51-\mathrm{B}$ \\
\hline
\end{tabular}




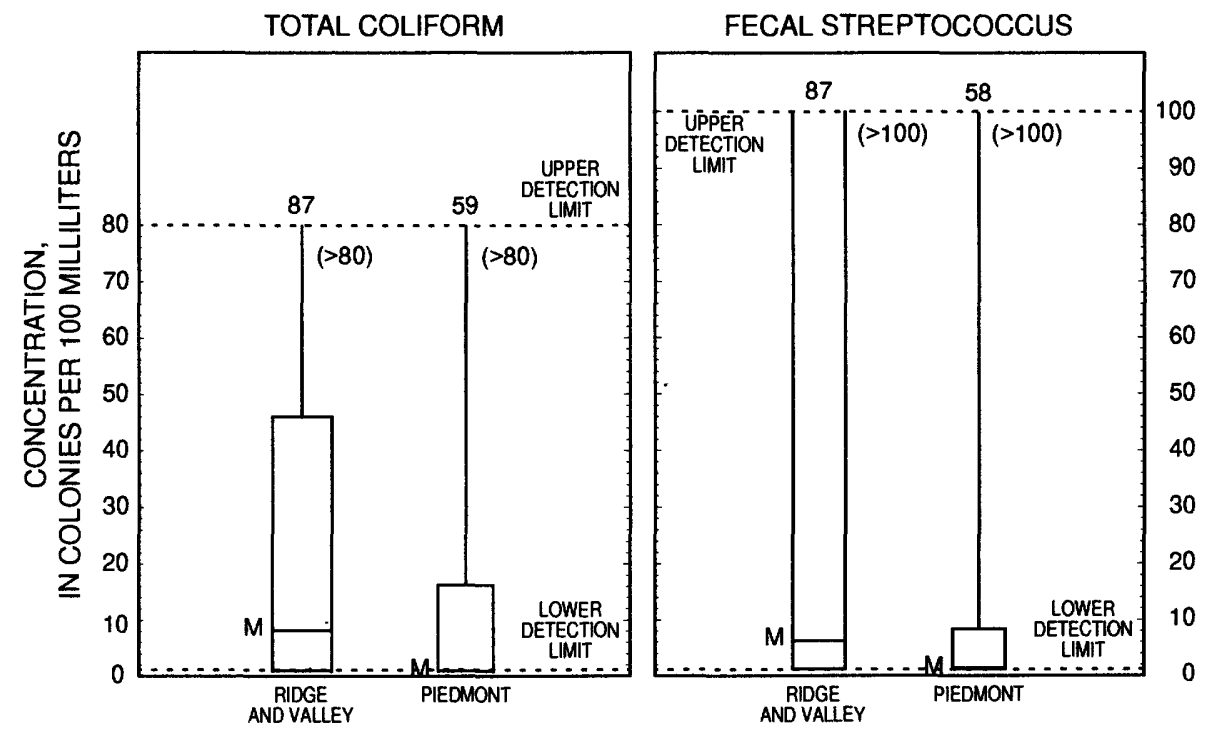

PHYSIOGRAPHIC PROVINCE

\section{EXPLANATION}

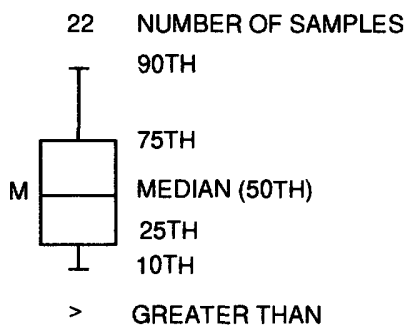

PERCENTILE - Percentage of analyses equal to or less than indicated values. If plot truncated at top, percentiles exceed upper detection limit.

Note: Plates with no colonies are reported as less than one colony per $100 \mathrm{~mL}$; therefore, the lower detection limit is one colony per $100 \mathrm{~mL}$. Plates with more than 80 total coliform colonies or 100 fecal streptococcus colonies were considered too numerous to count and reported as greater than 80 or greater than 100 colonies per $100 \mathrm{~mL}$, respectively. This is the upper detection limit for total coliform and fecal streptococcus.

Figure 8. Distribution of concentrations of total coliform and fecal streptococcus among physiographic provinces, Lower Susquehanna River Basin study unit, Pennsylvania and Maryland.

Table 5. Results of statistical analyses for relations between physiography and bacterial concentrations, Lower Susquehanna River Basin study unit, Pennsylvania and Maryland

[Values followed by the same letter are not significantly different as determined by Kruskal-Wallis Tests.]

\begin{tabular}{|c|c|c|}
\hline \multirow{2}{*}{ Probability } & \multicolumn{2}{|c|}{ Mean rank } \\
\hline & Ridge and Valley & Piedmont \\
\hline \multicolumn{3}{|l|}{ Total coliform } \\
\hline 0.008 & $81-A$ & $62-B$ \\
\hline \multicolumn{3}{|l|}{ Fecal coliform } \\
\hline .022 & $78-A$ & $66-B$ \\
\hline \multicolumn{3}{|l|}{ E. coli } \\
\hline .004 & $48-A$ & $35-B$ \\
\hline \multicolumn{3}{|l|}{ Fecal streptococcus } \\
\hline .001 & $83-A$ & $59-B$ \\
\hline
\end{tabular}




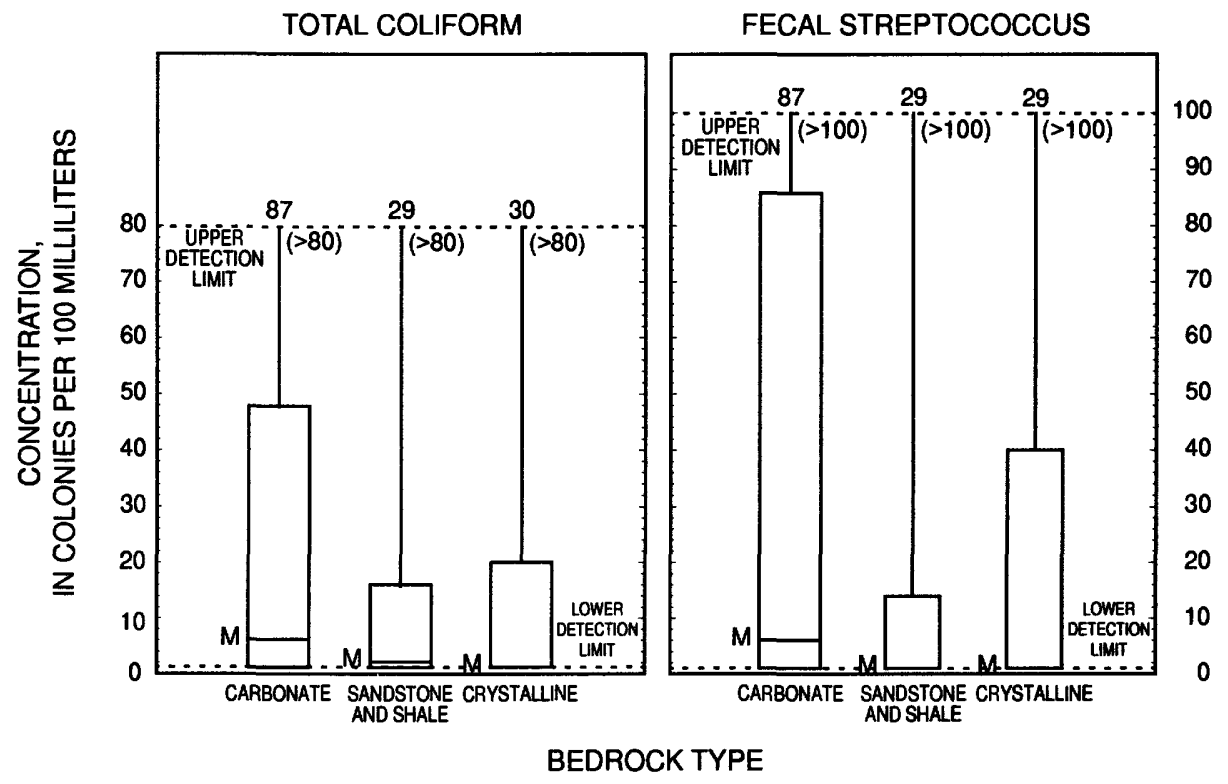

EXPLANATION

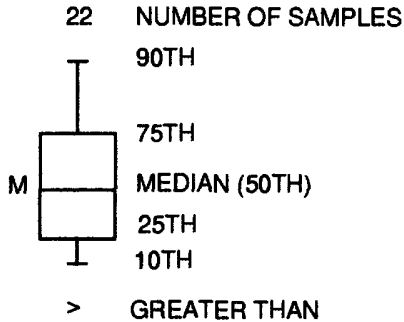

PERCENTILE - Percentage of analyses equal to or less than indicated values. If plot truncated at top, percentiles exceed upper detection limit.

Note: Plates with no colonies are reported as less than one colony per $100 \mathrm{~mL}$; therefore, the lower detection limit is one colony per $100 \mathrm{~mL}$. Plates with more than 80 total coliform colonies or 100 fecal streptococcus colonies were considered too numerous to count and reported as greater than 80 or greater than 100 colonies per $100 \mathrm{~mL}$, respectively. This is the upper detection limit for total coliform and fecal streptococcus.

Figure 9. Distribution of concentrations of total coliform and fecal streptococcus among bedrock lithologies comprising aquifers, Lower Susquehanna River Basin study unit, Pennsylvania and Maryland.

Table 6. Results of statistical analyses for relations between bedrock lithology comprising aquifer and bacterial concentrations, Lower Susquehanna River Basin study unit, Pennsylvania and Maryland

IValues followed by the same letter are not significantly different as determined by Kruskal-Wallis Tests; --, no $E$. coli samples were collected in areas underlain by sandstone and shale]

\begin{tabular}{|c|c|c|c|}
\hline \multirow[b]{2}{*}{ Probability } & \multicolumn{3}{|c|}{ Mean rank } \\
\hline & Carbonate & $\begin{array}{c}\text { Sandstone } \\
\text { and shale }\end{array}$ & Crystalline \\
\hline \multicolumn{4}{|l|}{ Total coliform } \\
\hline 0.070 & 80-A & 64-A & $63-A$ \\
\hline \multicolumn{4}{|l|}{ Fecal coliform } \\
\hline .065 & 78-A & $68-A$ & $65-A$ \\
\hline \multicolumn{4}{|l|}{ E. coli } \\
\hline .004 & $49-A$ & -- & $35-B$ \\
\hline \multicolumn{4}{|l|}{ Fecal streptococcus } \\
\hline .170 & $78-A$ & $66-A$ & $63-A$ \\
\hline
\end{tabular}



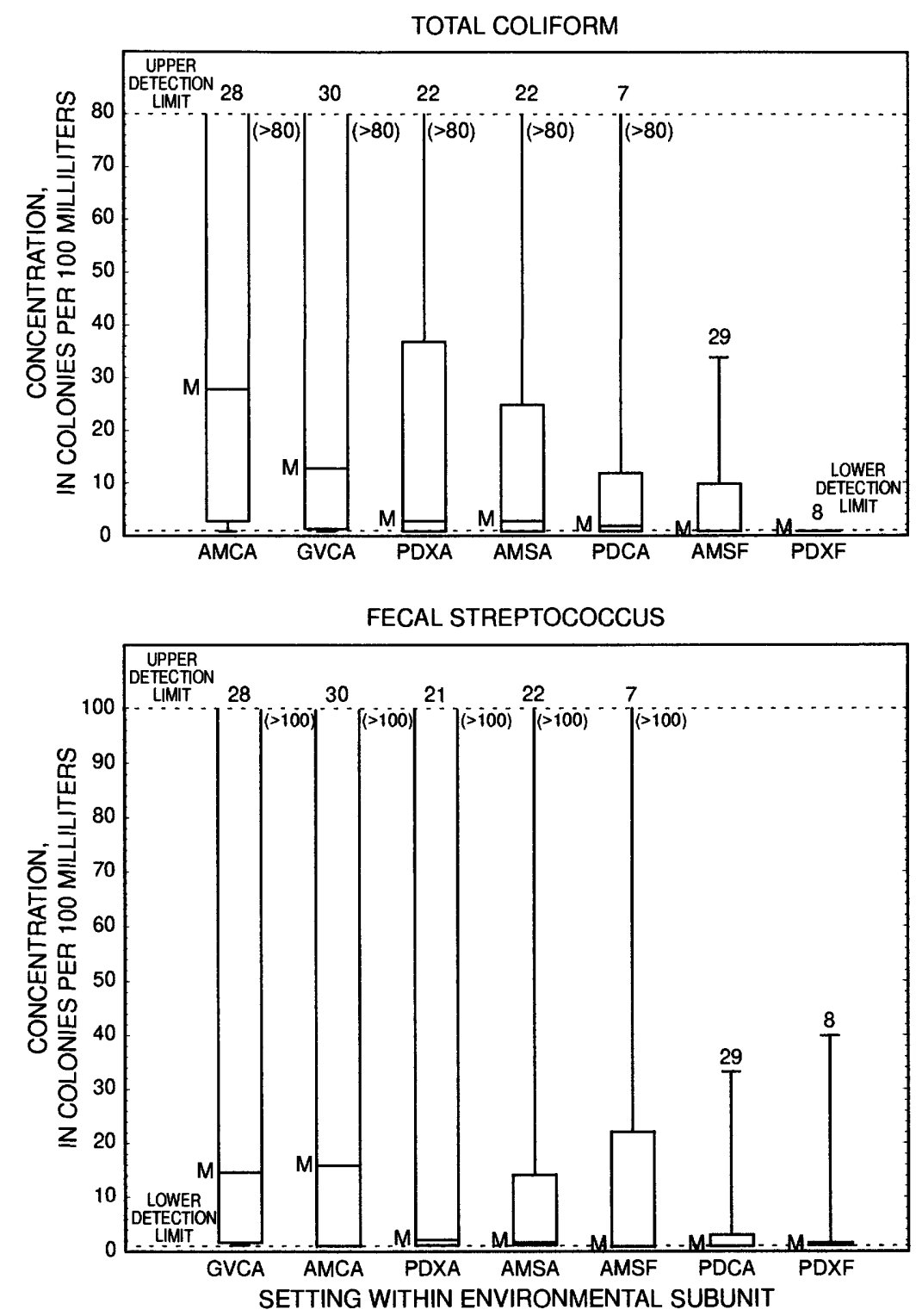

EXPLANATION

\section{SETTING ABBREVIATIONS}

GVCA - Great Valley carbonate subunit, agricultural setting

AMCA - Appalachian Mountain carbonate subunit, agricultural setting

PDXA - Piedmont crystalline subunit, agricultural setting

AMSA - Appalachian Mountain sandstone and shale subunit, agricultural setting

PDCA - Piedmont carbonate subunit, agricultural setting

AMSF - Appalachian Mountain sandstone and shale subunit, forested setting

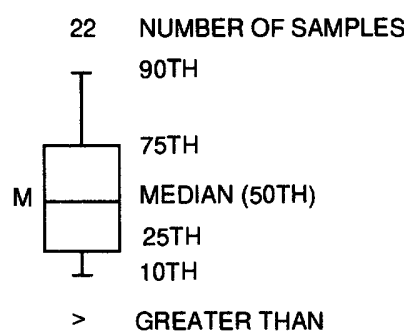

PDXF - Piedmont crystalline subunit, forested setting

Figure 10. Distribution of concentrations of total coliform and fecal streptococcus among land-use settings within environmental subunits, Lower Susquehanna River Basin study unit, Pennsylvania and Maryland.
PERCENTILE - Percentage of analyses equal to or less than indicated values. If plot truncated at top, percentiles exceed upper detection limit.

Note: Plates with no colonies are reported as less than one colony per $100 \mathrm{~mL}$; therefore, the lower detection limit is one colony per $100 \mathrm{~mL}$. or 100 fecal streptococcus colonies were considered too numerous to count and reported as greater than 80 or greater than 100 colonies per $100 \mathrm{~mL}$, respectively. This is the upper detection limit for total coliform and fecal streptococcus. Plates with more than 80 total coliform colonies 
Table 7. Results of statistical analyses for relations between land-use settings within environmental subunits and bacterial concentrations, Lower Susquehanna River Basin study unit, Pennsylvania and Maryland

[Values followed by the same letter(s) are not significantly different as determined by Kruskal-Wallis Tests; --, no $E$. coli samples were collected in that setting]

\begin{tabular}{|c|c|c|c|c|c|c|c|}
\hline \multirow[b]{2}{*}{ Probability } & \multicolumn{7}{|c|}{ Mean rank } \\
\hline & $\begin{array}{l}\text { Appalachian } \\
\text { Mountain } \\
\text { carbonate, } \\
\text { agricultural } \\
\text { setting }\end{array}$ & $\begin{array}{l}\text { Great Valley } \\
\text { carbonate, } \\
\text { agricultural } \\
\text { setting }\end{array}$ & $\begin{array}{l}\text { Piedmont } \\
\text { crystalline, } \\
\text { agricultural } \\
\text { setting }\end{array}$ & $\begin{array}{l}\text { Appalachian } \\
\text { Mountain } \\
\text { sandstone } \\
\text { and shale, } \\
\text { agricultural } \\
\text { sett ng }\end{array}$ & $\begin{array}{c}\text { Piedmont } \\
\text { carbonate, } \\
\text { agricultural } \\
\text { setting }\end{array}$ & $\begin{array}{l}\text { Appalachian } \\
\text { Mountain } \\
\text { sandstone } \\
\text { and shale, } \\
\text { nonagricultural } \\
\text { setting }^{1}\end{array}$ & $\begin{array}{c}\text { Piedmont } \\
\text { crystalline, } \\
\text { nonagricultural } \\
\text { setting }^{2}\end{array}$ \\
\hline \multicolumn{8}{|c|}{ Total coliform } \\
\hline 0.002 & $93-A$ & $85-A$ & $74-A B$ & $69-A B$ & $61-B$ & $51-B$ & 34-B \\
\hline \multicolumn{8}{|c|}{ Fecal coliform } \\
\hline .001 & $74-A$ & $98-A$ & $73-B$ & $66-B$ & $64-B$ & $57-B$ & $57-B$ \\
\hline \multicolumn{8}{|l|}{ E. coli } \\
\hline .014 & $46-A$ & $52-A$ & $37-B$ & - & -- & -- & $31-B$ \\
\hline \multicolumn{8}{|c|}{ Fecal streptococcus } \\
\hline .001 & $90-A$ & $91-A$ & $70-A B$ & $68-A B$ & 54-B & $61-A B$ & $43-B$ \\
\hline
\end{tabular}

1 This nonagricultural category consists of 7 wells in forested settings.

${ }^{2}$ This nonagricultural category consists of 7 wells in forested settings and 1 well in a suburban setting. 
Relations between Bacterial Concentrations and Selected Well and Water-Quality Characteristics

Statistical tests were conducted to determine the relations between bacterial concentrations and other continuous variables. The results of the tests of selected well characteristics and selected water-quality constituents are discussed.

In tests of bacterial concentrations and selected well characteristics, total coliform, fecal coliform, and fecal streptococcus were all statistically related to well age as indicated by probabilities less than 0.05 (table 8). However, these relations were weak. Total coliform, for example, is statistically related to well age as indicated by a probability of 0.001 . The correlation coefficient, however, is small $(0.298)$, which means that the relation is poor and probably insignificant in predicting the concentration of total coliform from the well age. There were no statistically significant relations between bacterial concentrations and the following: well depth, depth to bedrock, casing length, specific capacity, and depth to the first water bearing zone.

Statistically significant relations exist between bacterial concentrations and certain waterquality constituents as indicated by probabilities less than 0.05 (table 9). E. coli, for example, is associated with the concentration of total dissolved solids as indicated by a probability of 0.005 . The correlation coefficient is small (0.298), and the relation is probably insignificant in predicting the concentration of $E$. coli from the concentration of total dissolved solids. Concentrations of dissolved organic carbon were related with concentrations of total coliform, fecal coliform, $E$. coli, and fecal streptococcus. Similarly, relations were identified between concentrations of total dissolved solids and concentrations of total coliform and fecal coliform, between concentrations of ammonia plus organic nitrogen and concentrations of fecal coliform, and between concentrations of chloride and concentrations of total coliform. Although these relations are statistically significant based on the probability, the corresponding correlation coefficients (Spearman's rho) are all quite small. The small coefficients mean that the correlations are probably insignificant in predicting the concentration of bacteria from the concentration of the other water-quality constituents. 
Table 8. Summary of statistical correlations between bacterial concentrations and selected well characteristics, Lower Susquehanna River Basin study unit, Pennsylvania and Maryland

\begin{tabular}{|c|c|c|c|c|c|c|c|c|c|c|c|c|}
\hline Constituent & \multicolumn{3}{|c|}{ Total coliform } & \multicolumn{3}{|c|}{ Fecal coliform } & \multicolumn{3}{|c|}{ E. coli } & \multicolumn{3}{|c|}{ Fecal streptococcus } \\
\hline Well depth & -0.016 & 0.851 & 146 & 0.104 & 0.212 & 146 & 0.100 & 0.359 & 87 & 0.084 & 0.317 & 145 \\
\hline Depth to bedrock & -.117 & .253 & 97 & .072 & .486 & 97 & -.044 & .742 & 58 & .063 & .540 & 96 \\
\hline Well age & .273 & .001 & 144 & .206 & .013 & 144 & .038 & .72 & 85 & .298 & .000 & 143 \\
\hline $\begin{array}{l}\text { Depth to water- } \\
\text { bearing zone }\end{array}$ & -.102 & .33 & 93 & .083 & .427 & 93 & .038 & .783 & 54 & -.034 & .745 & 92 \\
\hline
\end{tabular}

Table 9. Summary of statistical correlations between bacterial concentrations and selected water-quality constituents, Lower Susquehanna River Basin study unit, Pennsylvania and Maryland

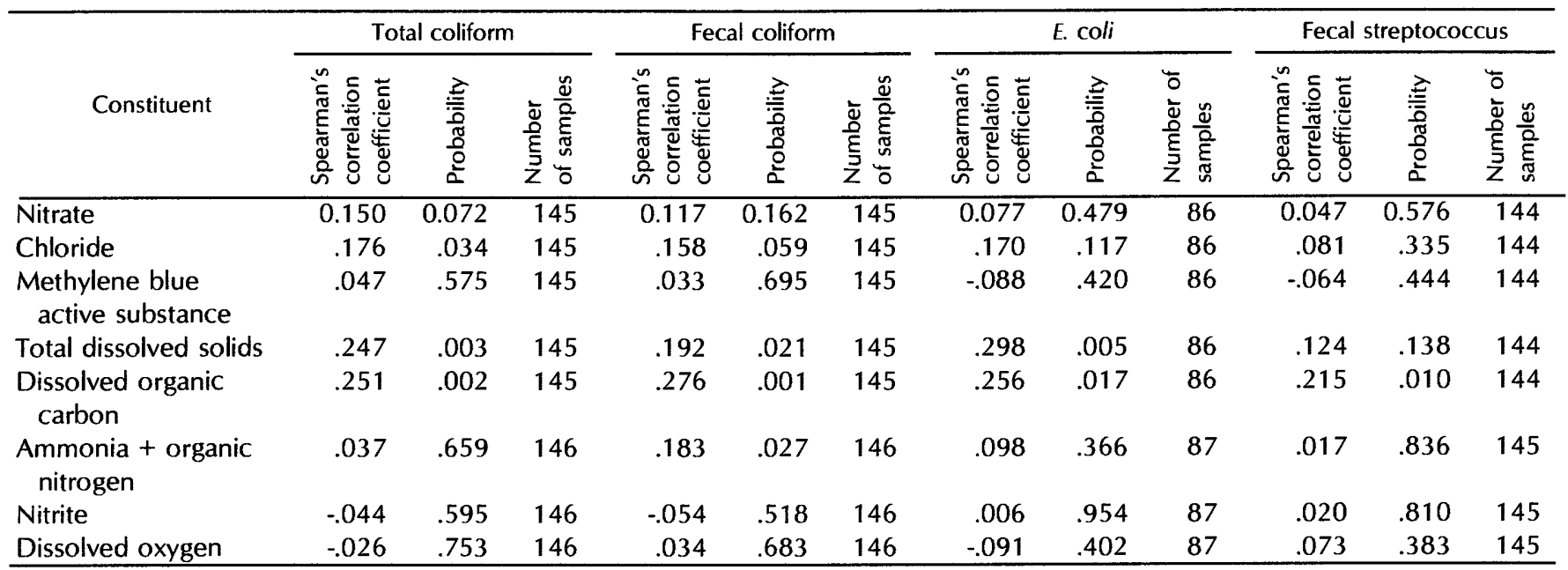




\section{Other Possible Factors Related to Bacteria in Ground Water}

The statistical analysis of the data shows that land use, physiographic province, and probably bedrock type are factors influencing the concentration of bacteria in ground water. Other factors that were not quantified in this study also may affect bacterial concentrations in well water. High concentrations of bacteria in well water may result when there is a bacteria source and a pathway for the bacteria to enter the aquifer or the well. Larger numbers of bacteria in the environment increase the chance that some bacteria will enter a well. Application of sludge from sewage treatment plants is not common and sites were chosen such that there were no feedlots within a half mile radius. Therefore, the most likely cause of increased quantities of bacteria in the environment near the wells sampled would be failed septic systems or manure applied to fields. Some well-construction characteristics could allow a direct path for bacteria to enter a well. Hydrogeologic structures that do not filter out all bacteria can also provide a path for bacteria to enter the aquifer. These factors could influence whether or not bacteria are detected in water from a well.

\section{Pathways for Bacteria to Enter into the Well}

Wells can be constructed to reduce or eliminate the number of pathways for contaminants to enter the water supply, however, deterioration of old wells and improper siting and installation of new wells could allow pathways for bacteria to enter a well directly (fig. 11). Bacteria could enter a well if (1) the top of the casing is not sealed and vented properly, (2) the annulus around the outside of the casing is not grouted, (3) there is leakage around the pitless adaptor, or (4) the casing is cracked or otherwise deteriorating. As previously noted, some differences in well-construction regulations exist, however, only six wells in Maryland and four wells in Chester County, $\mathrm{Pa}$., were sampled. Therefore, information on the effect of regulations was inadequate to conduct statistical analysis for this study. Casing caps, regulations and standards for well construction, and well deterioration and other age factors are discussed here as important considerations to minimize the number of pathways into the well.

Most wells sampled had a loose-fitting well cap on the top of the casing instead of a sanitary seal. Many of these wells had spiders, ants, earwigs, or other insects inside the well at the top of the casing. These insects can fall down the inside of the casing and introduce bacteria into the well (Wisconsin Department of Natural Resources, 1993). Some casings were cut off flush with the ground. This situation, combined with a loose well cap, could increase the chance that dirt or surface water could enter the well. Sanitary seals have an expanding rubber gasket that can prevent such things as dirt, spiders, insects, and surface water from entering the well through the top of the casing. Because only 3 of the 146 wells sampled had sanitary seals, analyzing the significance of this factor statistically was not possible. Nevertheless, the field observations made for this study show that casing caps were generally not sealed and represent a potential pathway for contaminants to enter the well.

Ungrouted wells are vulnerable to contamination. Regulations for well construction are written to include detailed requirements and standards for grouting (Chester County Health Department, 1993). Well-completion records for 108 wells indicated that grout was installed in 29 wells-23 in Pennsylvania and 6 in Maryland. The annulus of loose dirt or fill around the casing of an ungrouted well may be a pathway for bacteria-laden water to move down along the casing. 
Physical defects such as leakage around the pitless adaptor may have existed in some of the wells sampled. Wells in Maryland and Chester County, Pa., that do not pass the initial potability test must be retested, checked to ensure that there are no physical defects in the construction of the well, and evaluated for treatment options. Leakage around the pitless adaptor is another possible pathway for bacteria to enter a well.

The competence of a well casing is commonly related to the age of a well. The median age of the wells sampled was from 7 to 10 years old and only 3 of the 146 wells sampled were more than 20 years old. Because so few "old" wells were sampled, problems commonly associated with older wells such as well pits with standing water, inadequate casing length, and cracked or corroded casings were minimized. Lack of grouting could increase the deterioration rate of the well casing. Any crack or hole in the casing that is in the saturated zone provides a pathway for bacteria to enter into the well.

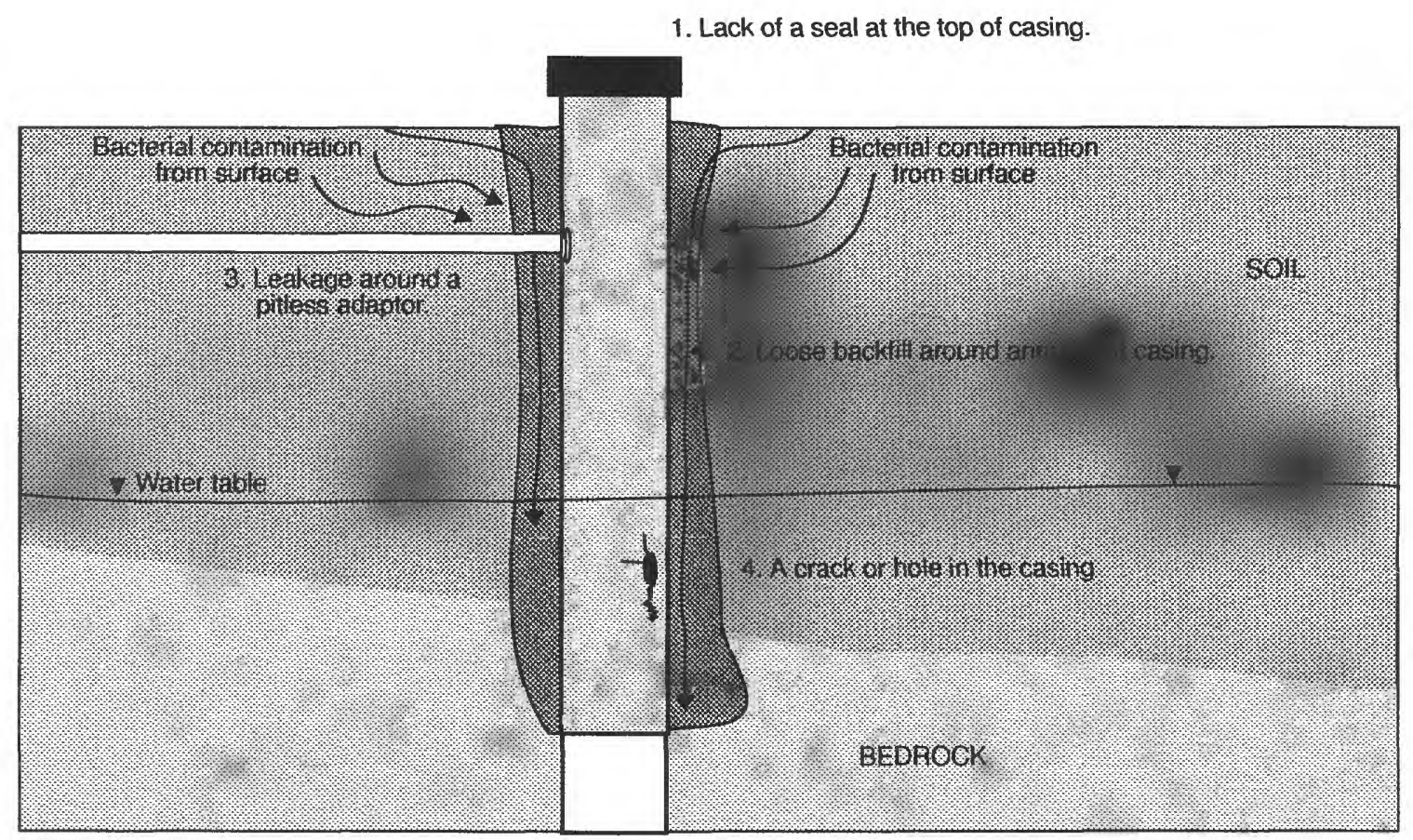

Figure 11. Pathways for bacterial contamination to enter into a well. 
Pathways for Bacteria to Enter into the Aquifer

Well-construction practices such as installing grout and a sanitary seal reduce the chance that bacteria will enter the well from surface sources of contamination, but that does not guarantee that bacteria will not be present in the well. If there is a pathway for the bacteria to enter the bedrock aquifer, well-construction practices cannot prevent bacteria from entering the well. Bacteria sources and pathways into the aquifer are illustrated in figure 12 .

Bacteria from a septic system could enter the aquifer directly if the septic system is not functioning properly. This is a factor that could not be quantified in this study but may have had an influence on the presence of bacteria. Any septic system can introduce bacteria into the aquifer if the depth to the fractured bedrock is very shallow. Depth to bedrock generally ranged from $10-90 \mathrm{ft}$ in the areas studied with a median bedrock depth of $30 \mathrm{ft}$ (Risser and Siwiec, in press). Commonly, however, bedrock outcrops are evident in fields near the sampling locations.

Bacteria from agricultural application of manure could enter the aquifer through paths such as sinkholes and areas with shallow bedrock (fig. 12). The timing of manure application with respect to a rainfall event may also increase the likelihood that bacteria would infiltrate the aquifer directly. In the above scenarios, the bacteria would be in the ground water, and any well that produced water from that aquifer would contain that bacteria, despite the well-construction characteristics.

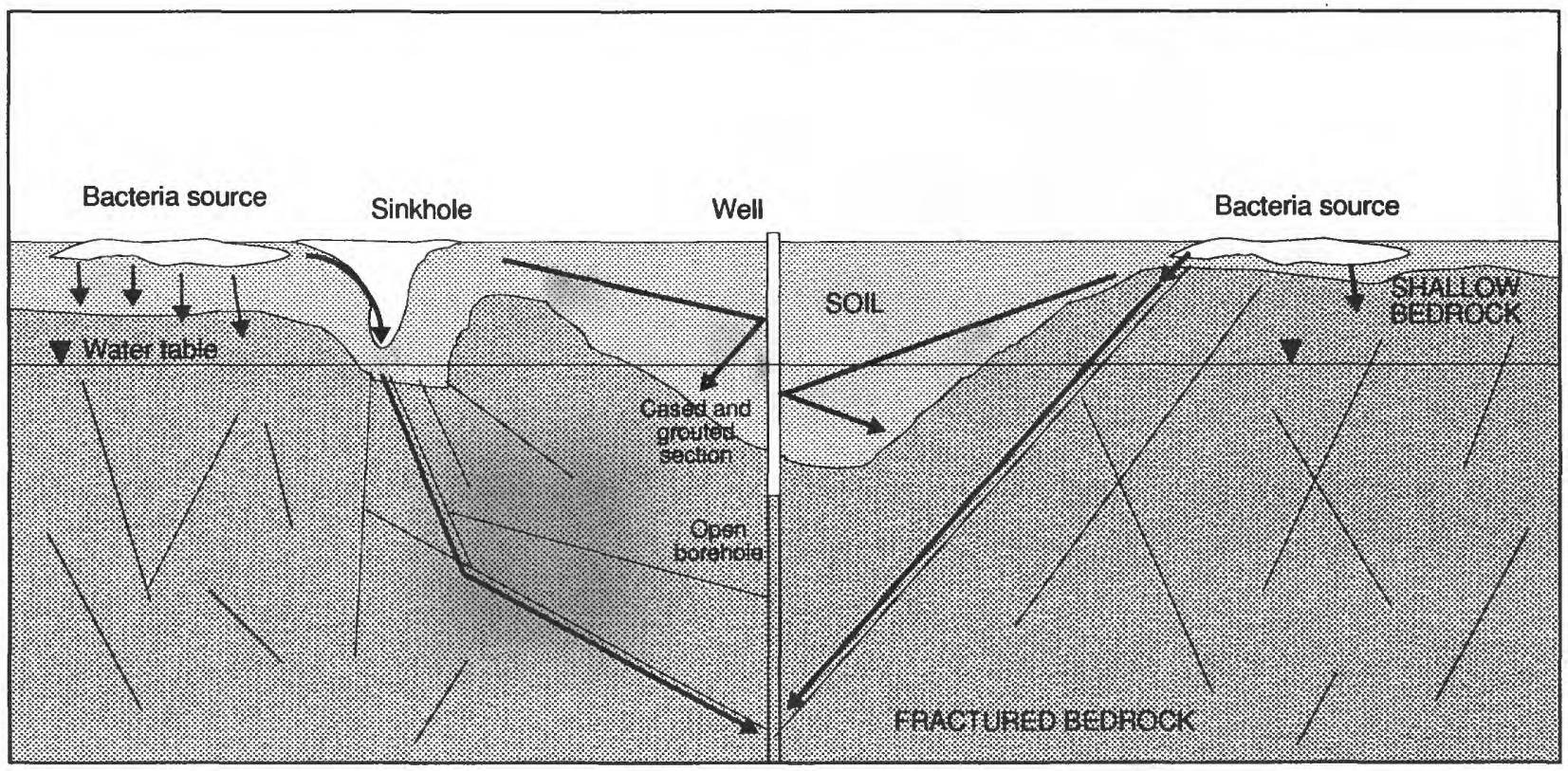

Figure 12. Pathways for bacterial contamination to enter into a bedrock aquifer. 
The bacteriological quality of raw ground water used for household water supply was assessed for this study. Water samples were collected from selected areas in the Lower Susquehanna River Basin study unit in 1993-95 from 146 wells in 17 counties in Pennsylvania and 2 counties in Maryland. Each well within the five subunits was sampled once. Subunit criteria include the land use, physiography, and bedrock lithology.

Bacteria were not found in water samples from 31 of the 146 wells sampled. Of the water samples collected, 101 tested positive for total coliform bacteria, and 34 tested positive for fecal coliform bacteria. Of the 145 samples that were collected for fecal streptococcus, 91 tested positive. E. coli testing was not conducted during 1993, the first year of the Lower Susquehanna River Basin study. Therefore, water from 88 of the 146 wells was tested for $E$. coli. Of those 88 water samples, 26 tested positive for $E$. coli bacteria. Nearly one-third of the samples that contained total coliform bacteria also contained fecal coliform bacteria. Fecal streptococcus bacteria was present in more than three-quarters of the samples that tested positive for total coliform bacteria and in all of the samples in which fecal coliform bacteria was present. The Great Valley and Appalachian Mountain carbonate subunits had the highest percentages of bacterial presence.

Statistical analyses were conducted to determine the relation between concentrations of bacteria and characteristics of environmental subunits. Statistical test results showed that land use and physiographic province are the variables that have the greatest affect on bacterial concentrations. The statistical analyses show that concentrations of total coliform, fecal coliform, and fecal streptococcus are significantly higher in agricultural areas than they are in nonagricultural areas. E. coli concentrations are not significantly different among land-use categories. All four bacteria types have concentrations that are higher in the Ridge and Valley Physiographic Province than the concentrations are in the Piedmont Physiographic Province. E. coli concentrations are significantly higher in areas underlain by carbonate bedrock. Other differences among bedrock types are not statistically significant at the 95-percent confidence level, yet are at the 93-percent confidence interval, which indicates a probable relation between bacterial concentrations and bedrock type.

Statistical tests also were conducted to determine if bacterial concentrations were related to selected well characteristics and concentrations of selected water-quality constituents. Some correlations exist between bacterial concentrations and well characteristics. Correlations also exist between bacterial concentrations and selected water-quality constituents. The results of the tests indicate the correlations are probably insignificant in predicting the concentration of bacteria from well characteristics or the concentration of the other water-quality constituents.

It is uncertain whether the aquifers sampled have widespread contamination or the bacteriological contamination is the result of site-specific factors. Other factors may exist, besides land use and physiography that could affect bacterial concentrations. These factors include hydrogeologic structures and whether or not 1) the septic system is functioning, 2) manure has been applied to nearby fields, or 3) the well has been protected from surface contamination by grout and a sanitary seal. The large number of wells that did not have sanitary seals and were not grouted made it difficult to determine if bacterial contamination was a result of aquifer contamination or well construction. Further study with an assessment designed to compare different well characteristics would provide the data needed to determine whether the aquifers sampled have widespread contamination or the bacteriological contamination is the result of sitespecific factors. 
American Public Health Association, American Water Works Association, and Water Pollution Control Federation, 1992, Standard methods for the examination of water and wastewater (18th ed.): Washington, D.C., American Public Health Association, 1,137 p.

Bordner, R.H., Winter, J.A., and Scarpino, Pasquale, eds., 1978, Microbiological methods for monitoring the environment, water and wastes: Cincinnati, Ohio, U.S. Environmental Protection Agency, EPA-600/8-78-017, 338 p.

Breen, K.J., and Dumouchelle, D.H., 1991, Geohydrology and quality of water in aquifers in Lucas, Sandusky, and Wood counties, Northwestern Ohio: U.S. Geological Survey Water-Resources Investigations Report 91-4024, 234 p.

Britton, L.J., and Greeson, P.E., 1989, Methods for collection and analysis of aquatic biological and microbiological samples: U.S. Geological Survey Techniques of Water-Resources Investigations, book 5, chap. A4, p. 13-53.

Chester County Health Department, 1993, Rules and regulations-Water well construction, monitoring wells, and individual semi-public water supplies: Chapter 500, Section 501, 24 p.

Commonwealth of Pennsylvania, 1976, Ground-water law in Pennsylvania: Department of Environmental Resources State Water Plan Water Laws and Institutional Arrangements, Background Report No. 2, p. 31-32.

Durlin, R.R., and Schaffstall, W.P., 1994, Water resources data, Pennsylvania, water year 1993, vol.2, Susquehanna and Potomac River Basins: U.S. Geological Survey Water-Data Report PA-93-2, 361 p.

1996, Water resources data, Pennsylvania, water year 1994, vol.2, Susquehanna and Potomac River Basins: U.S. Geological Survey Water-Data Report PA-94-2, 418 p.
Fishel, D. K., and Lietman, P. L., 1986, Occurrence of nitrate and herbicides in ground water in the Upper Conestoga River Basin, Pennsylvania: U.S. Geological Survey Water-Resources Investigations Report $85-4202,8$ p.

Francis, J.D., Brower, B.L., Graham, W.F., Larson, O.W., III, McCaully, J.L., and Vigorita, H.M., 1984, Technical Summary of the National Statistical Assessment of Rural Water Conditions: U.S. Environmental Protection Agency, EPA 570/9-84-004, 111 p. [Available from National Technical Information Service, Springfield, VA 22161 as NTIS Report PB88- 213517.1

Gabler, R., and Consumers Union of United States, eds., 1988, Is your water safe to drink?, Consumer Reports Books: New York, Consumers Union, p. 29-46.

Gilliom, R.J., Alley, W.M., and Gurtz, M.E., 1995, Design of the National Water-Quality Assessment Program-Occurrence and Distribution of Water-Quality Conditions: U.S. Geological Survey Circular 1112, 33 p.

Helsel, D.R., and Hirsch, R.M., 1992, Statistical methods in water resources: New York, Elsevier Science Publishing Company, Inc., 522 p.

Horowitz, A.J., Demas, C.R., Fitzgerald, K.K., Miller, T.L., and Rickert, D.A., 1994, U.S. Geological Survey protocol for the collection and processing of surface-water samples for the subsequent determination of inorganic constituents in filtered water: U.S. Geological Survey Open-File Report 94-539, $40 \mathrm{p}$.

Maryland Code (COMAR), Title 26, Subtitle 4, Chapter 4.

Mitchell, W.B., Guptill, S.C., Anderson, K.E., Fegeas, R.G., and Hallam, C.A., 1977, GIRAS - a geographic information retrieval and analysis system for handling land use and land cover data: U.S. Geological Survey Professional Paper 1059, 16 p. 


\section{SELECTED REFERENCES-CONTINUED}

Risser, D.W., and Siwiec, S.F., in press, Water-quality assessment of the Lower Susquehanna River Basin, Pennsylvania and Maryland- Environmental setting: U.S. Geological Survey Water-Resources Investigations Report 94-4245.

Scott, J.C., 1990, Computerized stratified random site-selection approaches for design of a ground-water-quality sampling network: U. S. Geological Survey WaterResources Investigations Report 90-4101, $109 \mathrm{p}$.

Sharpe, W.E., Mooney, D.W., and Adams, R.S., 1985, An analysis of groundwater quality data obtained from private individual water systems in Pennsylvania: Northeastern Environmental Science, v.4, no. 3/4, p. 155-159.

U.S. Bureau of the Census, 1992, Census of population and housing, 1990: Washington, D.C., Summary Tape File 3 on CD-ROM [machine-readable data files].
U.S. Environmental Protection Agency, 1991, Test methods for Escherichia coli in drinking water: Cincinnati, Ohio EPA/600/4-91/016, 2 p.

1994, National Primary Drinking Water Standards: Washington D.C., EPA 810-F-94-001A, 4 p.

Wisconsin Department of Natural Resources, Bureau of Water Supply, 1993, Earwigs in your well: Madison, Wisconsin, PUBL WS-029 93, 1 p.

Yates, M.V., and Yates, S.R., 1993, Pathogens, in Alley, W.M., ed., Regional Ground-Water Quality: New York, Van Nostrand Reinhold, p. 383-404. 